$4-2013$

\title{
Influences of an Honors Program on Students at a Faith-based University: A Qualitative Study
}

Carla Gaines

Cedarville University

Follow this and additional works at: http://digitalcommons.cedarville.edu/education_theses

Part of the Education Commons

\section{Recommended Citation}

Gaines, Carla, "Influences of an Honors Program on Students at a Faith-based University: A Qualitative Study" (2013). Master of Education Research Theses. 58.

http://digitalcommons.cedarville.edu/education_theses/58 
Running head: HONORS PROGRAM AT A FAITH-BASED UNIVERSITY

\title{
INFLUENCES OF AN HONORS PROGRAM ON STUDENTS AT
}

A FAITH-BASED UNIVERSITY: A QUALITATIVE STUDY

\author{
A thesis submitted in partial fulfillment \\ of the requirements for the degree of \\ Master of Education
}

By

CARLA DAWN GAINES

B.S. Biology, Cedarville University, 2002

2013

Cedarville University 


\title{
HONORS PROGRAM AT A FAITH-BASED UNIVERSITY
}

\begin{abstract}
Gaines, Carla D. M.Ed., Education Department, Cedarville University, 2013. The Influences of an Honors Program on Students at a Faith-based University.
\end{abstract}

American colleges and universities, including faith-based institutions, continue to actively recruit gifted college students through educational opportunities such as honors programs. Other research also indicates that the college campus context, challenging academic experiences, and diverse social interactions can have varying effects on students' psychosocial development. Understanding the influences of these multiple factors on honors students can potentially provide insights into the effectiveness of these programs and their objectives. Using a qualitative research design, this study investigated the experiences and perceptions of honors students at a faith-based university. The participants indicated that through the honors program they were encouraged to pursue genuine life integration, excellence as a mindset, and self-authorship in their respective identities and worldviews. These objectives were encouraged through purposeful exposure to diverse content and individuals, a secure learning community, and faculty examples. Within each of these areas, the students also highlighted the effects on their spiritual development resulting from the integrated approach to spiritual beliefs and academics and daily living. 
HONORS PROGRAM AT A FAITH-BASED UNIVERSITY

Table of Contents

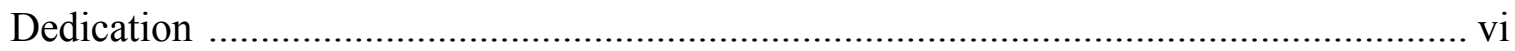

Acknowledgements ........................................................................................... vii

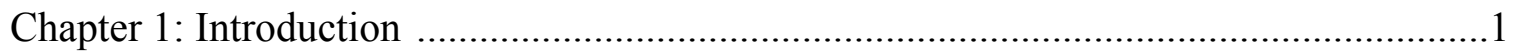

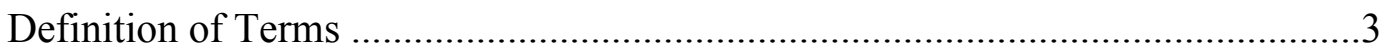

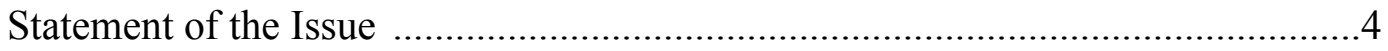

Scope of the Study and Delimitations ..................................................................

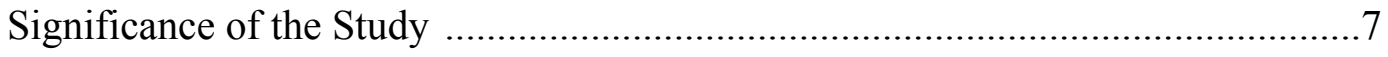

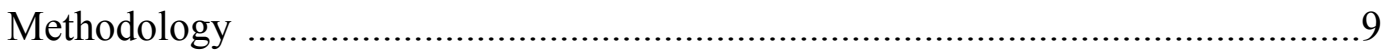

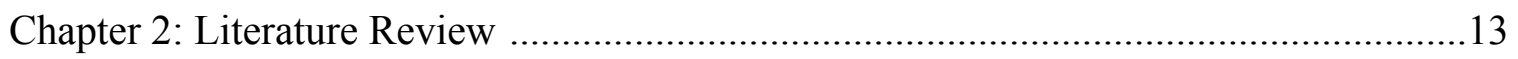

Gifted College Students ............................................................................13

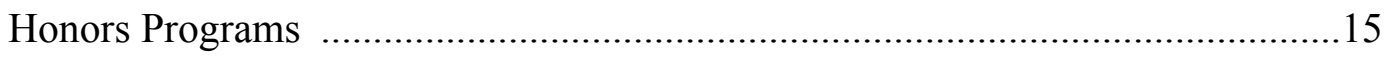

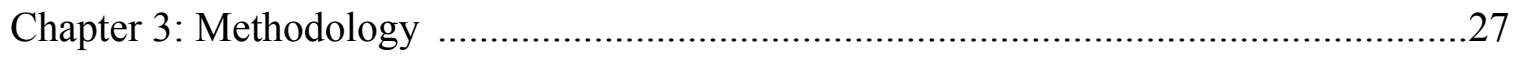

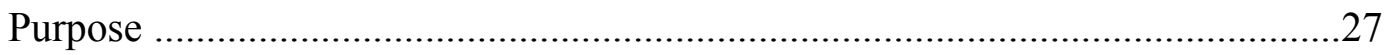

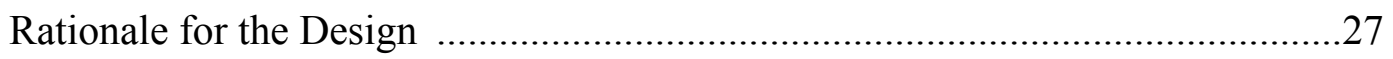

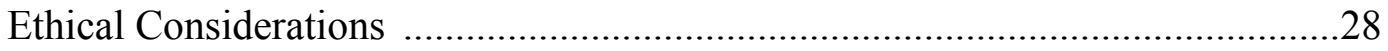

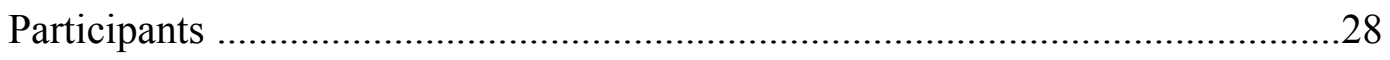

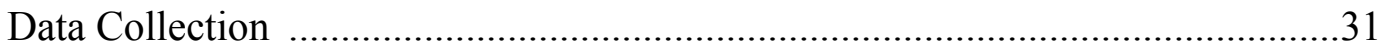

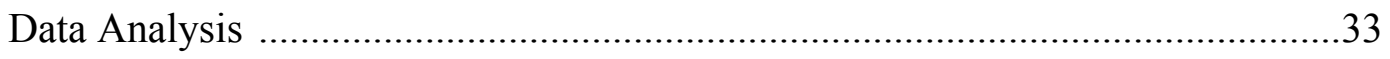

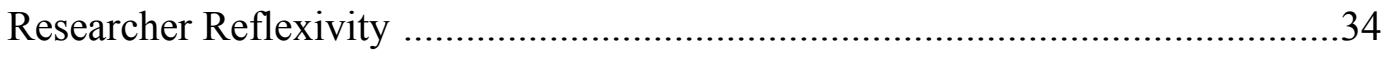

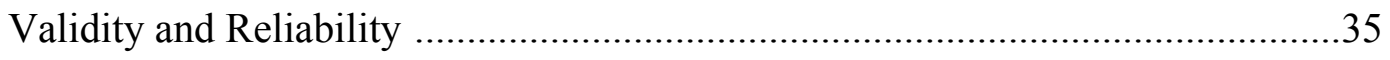

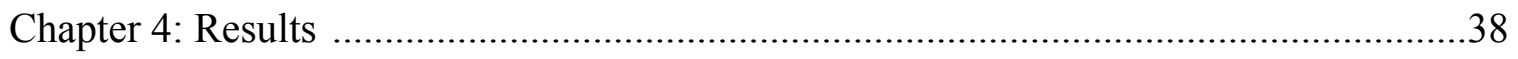

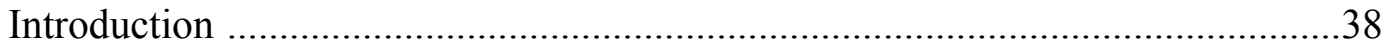


HONORS PROGRAM AT A FAITH-BASED UNIVERSITY

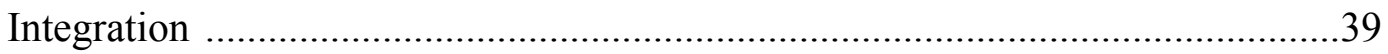

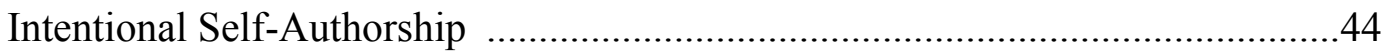

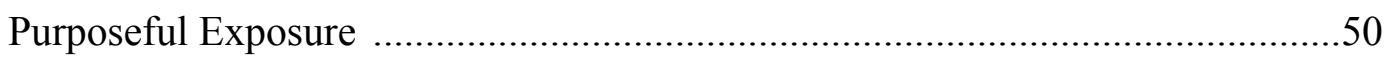

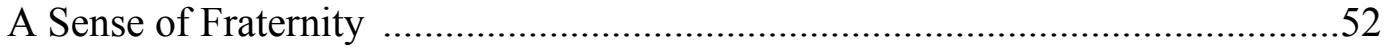

Faith-based Academics . ........................................................................61

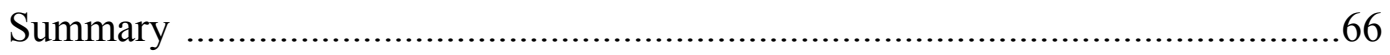

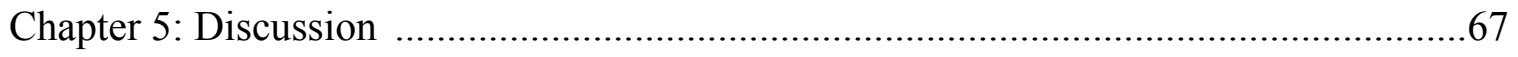

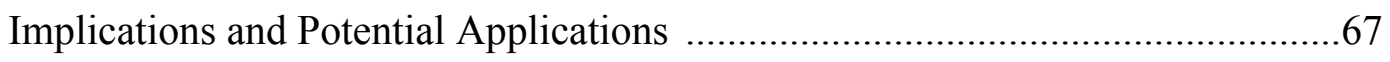

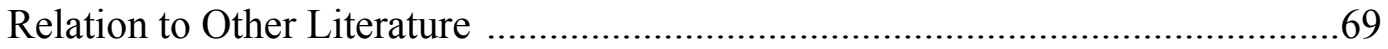

Biblical Integration Component and Implications ...................................... 74

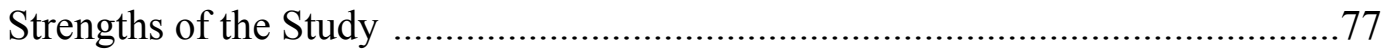

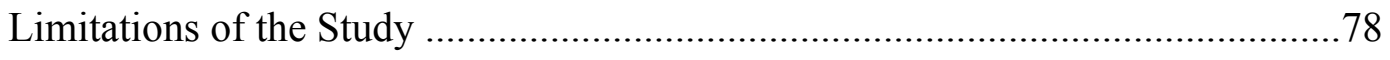

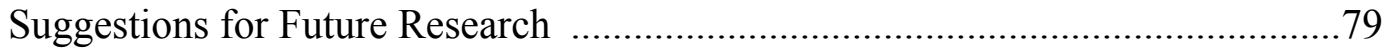

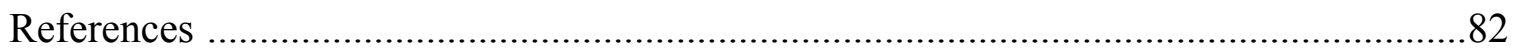

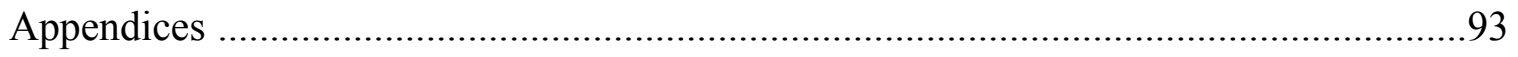




\section{HONORS PROGRAM AT A FAITH-BASED UNIVERSITY}

\section{Dedication}

I dedicate this thesis project to my husband, Stephen, and daughters, Mackensie and Brianna. They have sacrificed countless hours and opportunities supporting me in this endeavor. They have encouraged me and supported my continuation regardless of how long or difficult the road might be. They have been my inspiration and I cannot thank them enough. As a result of their presence in my life, I can look at this project as complete. Thank you, with all my heart. 
HONORS PROGRAM AT A FAITH-BASED UNIVERSITY

\section{Acknowledgements}

In addition to my immediate family, I wish to acknowledge the many individuals who were essential to the completion of this project. First and foremost, I thank my Lord and Savior, Jesus Christ. Through this project, I encountered several opportunities to quit when personal or financial resources would not be available. In each situation, however, the precise needs were fulfilled completely and I was able to see this project to its finish.

Several family and friends also facilitated this project by providing childcare so I

could concentrate on the work. These individuals include Charles \& Barbara Stoltenberg, Herbert \& Jane Gaines, Joanna Ehlers, Elaina Stoltenberg, Allie Brown, and Annelise Schick. In addition, I wish to acknowledge the faculty and staff at Cedarville University who provided me with encouragement, support, insight, and guidance throughout this process. These individuals include Dr. Stephen Gruber, Dr. Michael Firmin, Dr. Ed Baumann, Dr. Thomas Mach, Dr. David Mills, Ms. Toi King, and Mrs. Kim Wade. I could not have completed this thesis without each and every person mentioned here. Finally, I extend my appreciation to my church family at Emmanuel Baptist Church and my friends at iMom - Xenia. I know they lifted an incalculable number of prayers to heaven on my behalf. Thank you all for everything. 


\section{HONORS PROGRAM AT A FAITH-BASED UNIVERSITY}

\section{Chapter 1: Introduction}

American colleges and universities are encountering an era of significant change in the way people approach higher education. In response, researchers are increasingly attempting to understand both the various elements of higher education and the people who experience those elements. While college students have always been a subgroup of interest, Arnett (2011) theorized that the period between the ages of 18-25 now marks a new, distinct developmental stage, which he labeled "emerging adulthood." Arnett suggests that cultural shifts towards greater freedom and individualism have initiated a new stage of exploring, practicing, and identity-forming for the college-age population. He further asserts that these changes have removed many foundational support networks that formerly aided individuals in their identity formation and practice, resulting in patterns of instability, change, trial and error, and isolation for these young people.

At the same time, students have been approaching higher education much differently than they did in the past (Altbach, Gumport, \& Berdahl, 2011). As costs rise and a college degree becomes increasingly important in the job market, more students are attempting to complete college while juggling other significant responsibilities such as family and full-time jobs. Many students are also pursuing their degrees by attending multiple institutions, attending only part-time, or completing requirements through distance learning (Siegle, 2011). As a result, institutions must compete even more strategically for their constituents (Altbach, et al., 2011) and they have increasingly recruited the highest achieving students as one way to address these challenges (Wilson \& Adelson, 2012). Colleges and universities make significant investments expecting that these students will improve the broader academic environment, thereby increasing the 


\section{HONORS PROGRAM AT A FAITH-BASED UNIVERSITY}

schools' marketability to all potential students (Clauss, 2011). However, more research is needed in order to determine whether or not these investments genuinely accomplish their intended purposes.

Colleges and universities frequently have implemented honors programs in order to meet the needs of the high-achieving students they recruit (Schroeder, Bruce, \& Bogue, 2011). The published research literature is unclear whether all students accepted into honors programs previously had been identified prior to college as gifted students. However, acceptance into honors programs usually has required standardized test scores consistent with scores earned by formally identified gifted students (Wilson \& Adelson, 2012). Other educational enhancements have also been available, such as the College Level Examination Program, Advanced Placement, the International Baccalaureate, dual enrollment, and early entrance programs (Boazman, 2011; Kronholz, 2011; Perrone, Wright, Ksiazak, Crane, \& Vannatter, 2010). While these options provided some benefits through acceleration, only honors programs and early-entrance programs indicate that gifted students receive a qualitatively different college experience from a comprehensive perspective (Boazman, 2011). On the other hand, Robbins (2010) noted that students who chose not to finish their honors program did not perceive the benefits as worth the required investment. First, they felt that the university did not organize and promote the program well enough for the students to discern its value. Second, the honors program did not offer enough tangible benefits, such as early registration, financial aid, or housing, to justify the extra work. They considered the quality of their regular programs and other activities adequate for obtaining jobs and graduate school acceptance. 
HONORS PROGRAM AT A FAITH-BASED UNIVERSITY

These conflicting perspectives indicate that further research should be conducted in order to determine the future prospects for honors programs. Participants frequently described natural learning communities that supported both their academic and personal development in ways unique from their non-honors experience (Wawrzynski, Madden, \& Jensen, 2012; Zieniuk, 2012). However, researchers have expressed hesitation about inferring too much from the results of these studies. Quantitative survey results have documented what students self-report on particular measures, but have not explained how or why these results occurred, or whether uncontrolled factors from the students or the programs may have influenced the results (Dai, Swanson, \& Cheng, 2011). Qualitative studies have provided more salient insights into the complex interactions between individual characteristics, institutional characteristics, and distinct honors contexts. Unfortunately, these results cannot often be generalized beyond the specific groups of students investigated (Mosier, 2012). As a result, additional qualitative research should be completed in a wide cross-section of institutions in order to provide a more comprehensive view of how honors programs influence the lives of gifted college students.

\section{Definition of Terms}

Gifted student. Students who falls within the "upper 3\% to 5\% compared with their same age peers in general intellectual ability, distinguished academic competence in one or more domains, and creativity" (Pfeiffer, 2012, p. 5). No definition is nationally applied, but this is the typical guideline used for the majority of K-12 schools in the United States (Mcclain \& Pfeiffer, 2012). 
HONORS PROGRAM AT A FAITH-BASED UNIVERSITY

Gifted college student. A student who meets the minimum entrance requirements to a college or university honors program (Wilson \& Adelson, 2012).

Collegiate honors program. Any discipline-specific or interdisciplinary program at a post-secondary institution with the goal of providing enrichment or acceleration beyond the typical college course of study (England, 2010).

Senior honors student. A student who is currently enrolled in or has recently completed the capstone honors course as designated by the institution's honors curriculum.

Religiously affiliated institution. An institution that maintains "a direct and continuing influence on the institution by the sponsoring religion that can be clearly observed in some way in the governance, community, institutional identity or strategic operations of the university or college" (Arthur, 2006, p. 13).

Faith-based institution. An institution that maintains a mission or purpose statement rooted in the historic Christian religious tradition, focuses on the integration of faith, scholarship, and service in both curricular and extra-curricular activities, and employs only faculty and staff who profess a redemptive faith in Jesus Christ ("CCCU Profile 2012-2013;" Kuh \& Gonyea, 2006). Such institutions may hold membership in organizations such as the Council for Christian Colleges and Universities, but this status is not necessary (Kuh \& Gonyea, 2006).

\section{Statement of the Issue}

Colleges and universities across the United States continue to offer honors programs and other curricular modifications in order to attract and serve their highest achieving students (Boazman, 2011). Faith-based institutions also have contributed to this 
HONORS PROGRAM AT A FAITH-BASED UNIVERSITY

trend. According to Peterson's Christian Colleges \& Universities (2002), 79 members of the Council for Christian Colleges \& Universities (CCCU) offered some type of honors program in 2002. After reviewing each institutional website, I determined that $89 \mathrm{CCCU}$ schools now offer either an honors program or honors college (See Appendix A).

Additionally, membership status in the National Collegiate Honors Council has increased from 30 members to 38 since 2010 (“Member List," 2010; 2013). While several researchers have qualitatively studied various types of honors programs and their students, none could be located that investigated honors programs within the context of a faith-based institution. In the absence of previous research on the topic, I examined the intersection of these two dimensions by describing the experiences and perceptions of honors students at a faith-based institution of higher learning.

\section{Scope of the Study and Delimitations}

In this study, I limited data collection to conducting in-depth interviews with senior honors program students at a selective, private, comprehensive university located in the Midwestern United States. Through qualitative analysis, I strove to provide a voice for honors students by describing their experiences and how they believed those experiences shaped their respective lives. The institution I investigated enrolls approximately 3,400 students, composed primarily of Caucasian, 18- to 22-year-olds. Ninety-two percent of students fit a more traditional college student profile with $76 \%$ of students residing in campus housing and 16\% living in the local communities. The other $8 \%$ of students are considered "non-traditional," which include non-residential students taking only dual enrollment, online, or graduate courses. While the campus is located in a small, rural community, students can also access a variety of diverse curricular and extra- 


\section{HONORS PROGRAM AT A FAITH-BASED UNIVERSITY}

curricular experiences in multiple urban and metropolitan areas within 75 miles of the campus. The university is fully accredited by the North Central Association of Colleges and Schools (NCA) and maintains full membership in the CCCU.

I invited senior honors students to participate in semi-structured interviews in order to investigate the potential impact of the honors program on their academic development. In order to receive acceptance into the honors program, students earned a minimum composite score of 29 on the ACT or 1290 on the SAT, and completed an application process evaluating their academic, leadership, community, and writing accomplishments. In order to be classified as senior honors students, they had completed the majority of their general education, degree and honors requirements. None of the participants had elected to complete the senior research project. They all were currently enrolled in the senior honors colloquium at the time of the study. Through this honors program, students take part in interdisciplinary and liberal arts study, small discussionbased classes, and honors-oriented extra-curricular opportunities in accordance with many of the best practices outlined by NCHC guidelines ("Constitution \& Bylaws," 2013).

Certain limitations were introduced to the degree of generalization from the research conclusions due to the selected sampling methods. For the present qualitative study I selected only seniors who had completed most of the honors sequence at a single institution. The research objective was to obtain a single snapshot, versus a more longitudinal view, regarding how the honors program affected student academic and personal development (Fisler et al., 2009). One rationale for this sample was that very little time had passed between participants' reflections and the actual lived experiences. 


\section{HONORS PROGRAM AT A FAITH-BASED UNIVERSITY}

However, these students still exhibited several characteristics over emerging adulthood. Therefore, they likely have continued to evaluate their perceptions following the completion of this study (Arnett, 2011; Labouvie-Vief, 2006). Despite this limitation, the students' reflections on this program's influences have contributed additional perspectives to the collective understanding of honors programs that had not yet been addressed.

Finally, my biases as the researcher to some degree could not be separated from the process of the qualitative study. The mutual dialogue of interviews is inevitably a social interaction, blending the perspectives of interviewer and participants (King \& Horrocks, 2010). In order to mediate this bias, I triangulated information about the program from several additional sources and engaged with participants multiple times to verify consistency of responses, thereby improving the internal validity (Seidman, 2006).

\section{Significance of the Study}

Multiple cultural factors have pressured institutions of higher learning to reevaluate how they provide an effective college education. Economically, both institutions and students have invested more resources to accomplish their goals (Altbach et al., 2011). Philosophically, institutions have contended with the increasing influence from government and business, the shift of students from learners to consumers, and the impact of college rankings on students' college decisions (Badenhausen, 2012; Wilson \& Adelson, 2012). Accordingly, colleges and universities have labored to demonstrate their effectiveness and attract high-performing students who will, in return, benefit the institutions by offering educational incentives such as honors programs (Schroeder et al., 2011). Blossoming technological advances, however, have provided other opportunities 


\section{HONORS PROGRAM AT A FAITH-BASED UNIVERSITY}

for these students, such as dual enrollment and online courses. These options frequently offer a less expensive approach to a college degree for both institutions and students (Kronholz, 2011; Siegle, 2011). Therefore, as tangible returns on investment have become more important to college students, even gifted students, exploring the effectiveness and value of honors program has become even more important (Badenhausen, 2012; Dooley, 2011).

Faith-based institutions encounter these same pressures, and often more acutely, because the respective missions of these schools result in only private funding and attracting a narrower set of applicants (Peruso, 2011). However, the objectives of faithbased colleges and universities typically have encompassed broader concerns than just awarding students a degree. Administrators and faculty accept that the college period of development encompasses a host of transitions in the thinking, attitudes, beliefs, and practices of college students (Arnett, 2011). Therefore, these institutions have purposed to provide students with not only knowledge and job skills, but also train them to guide their lives by their beliefs, and maintain these beliefs in a pluralistic culture (Arthur, 2006; Franklin, 1995). These goals are often seen as conservative in nature, being rooted in historical and religious traditions and practices. In contrast, honors programs are often characterized by their emphasis on broad liberal arts ideals that some might perceive as contradictory to the more conventional purposes of faith-based schools. Descriptions of honor students' experiences contribute beneficial feedback to better understand just how these programs influence the students' development at these institutions and whether the programs benefit or hinder their missions (Mitchell, 2010). Program directors may also 
HONORS PROGRAM AT A FAITH-BASED UNIVERSITY

use the results to identify effective aspects of their programs that need improvement (Bratt, 2010).

\section{Methodology}

Research question: How has involvement in a college honors program at a faithbased institution influenced the intellectual, social, emotional, and spiritual development of college seniors?

I endeavored through this study to describe the development students experienced in relation to their participation in an honors program at a faith-based institution. The scarcity of previous research in this area did not provide a sufficient theoretical framework on which to base axial coding for a qualitative research study. Therefore, I determined that an exploratory, phenomenological research design, using an open coding format, best examined the research question through the use of in-depth interviews, presenting the experiences and perceptions of the participants in their own words (Merriam, 2009).

I investigated multiple constructs within this study in order to gain a holistic understanding regarding the potential influence of this particular honors program. Several studies suggested that honors programs offered academic challenge and meaningful learning that lead to greater academic achievement and self-concept (Cossentino, 2007;

Seifert, Pascarella, Colangelo, \& Assouline, 2007). By addressing both the academic and student life experiences connected to the honors program, I examined how students perceived these experiences to have shaped their intellectual and personal development and to what degree they viewed them as positive or negative influences. I also explored how the students related these experiences to their spiritual development and how the 


\section{HONORS PROGRAM AT A FAITH-BASED UNIVERSITY}

honors program may have challenged or reinforced this development. Research has demonstrated that the college experiences, particularly liberal arts experiences typical of honors programs, challenged previously held beliefs (Bryant, 2011; Hébert \& McBee, 2007). In contrast, other studies revealed that faith-based institutions created social and academic environments that reinforced the beliefs and practices of the enrolled students (Hill, 2009). Even though some change was expected because of the maturation process (Arnett, 2011), exploring the experiences of honors students and their reflections on those experiences contributed valuable insights into the college developmental process.

Through criterion sampling, I obtained a cohort of senior honors students from whom I gathered information-rich perspectives (Kvale \& Brinkmann, 2009). I invited participants based on three criteria: 1) current status as an honors student; 2) classification as a senior student; and 3) enrollment in either the honors senior colloquium or the honors senior research project. This sampling method resulted in 25 participants; fourteen were interviewed during a first wave of interviews and 11 during a second wave. I limited this study to senior students in order to gain access to the most complete experience of the honors program and its influences. The selectiveness diminished the breadth of perspectives, but produced a more thorough understanding of each participant's narrative (Creswell, 2013).

I conducted semi-structured interviews, each lasting about 30 minutes. The semistructured format permitted flexibility during the interview process, enabling the participants to highlight areas that were most meaningful to them, and perhaps identify constructs I had not specified (Seidman, 2006). After obtaining informed consent, I audio recorded and transcribed [verbatim] each interview. Following transcription, I requested 


\section{HONORS PROGRAM AT A FAITH-BASED UNIVERSITY}

all participants to verify their respective transcripts and respond to any follow-up questions or clarifications.

In order to acquire comprehensive and historical perspectives of the honors program, I interviewed the honors director, the professor who leads the honors senior colloquium, and one additional honors faculty member. These interviews lasted approximately 30 to 40 minutes and investigated the history, goals, and curriculum of the honors program. I also explored how the director and faculty have attempted to meet the academic, personal, and spiritual needs of the students they serve through the program. These additional perspectives added to the validity of the experiences described by the students and provided a more detailed framework of the program through which to understand their experiences (Patton, 2002).

I followed an inductive approach for data analysis, allowing the participants to speak for themselves (Creswell, 2013). General observations flowed from the careful review of interview transcripts, in contrast to deductively analyzing their relationship to a defined theoretical construct. I coded transcripts by noting repeated words, phrases, and shared constructs in order to identify patterns, themes, and categories according to techniques outlined by Miles and Huberman (1994). I then compared patterns and generalizations about participants' experiences to existing literature on both honors students and institutional context.

The results shared in the present thesis represent the consensus of the participants at large. Negative case assessment (Corbin \& Strauss, 2008) was used as part of the process of generating reported themes. Internal validity for the study was strengthened through a number of means. I used member checking (Mero-Jaffe, 2011), which involved 


\section{HONORS PROGRAM AT A FAITH-BASED UNIVERSITY}

showing the results of the study to a sample of participants and asking them to verify their general agreement with the themes reported in the present thesis. A data audit (Rodgers, 2008) was generated in which I provided a reasonably thorough list of quotes from various participants that supported each reported theme. Both depth and breadth of quotations from the transcripts helped to ensure the findings were adequately grounded in the transcript data. The use of expert independent review (Flick, 2006) helped to strengthen the study's internal validity. This involved having an expert in qualitative methodology review my data and data trail in order to help ensure the results being reported were reasonable representations of the participants' overall sentiments. The expert also reviewed the thoroughness of the qualitative research process followed in the study. Low inference descriptors (Chenail, 2012) were utilized when writing-up the results of the present study. Utilizing both breadth and depth of quotations from the participants' transcripts helped to ensure that the reported findings were ample reflections of the actual words spoken by the participants when interviewed. In sum, the process followed in the present thesis is believed to be a good reflection of standard, rigorous qualitative methodology (Sin, 2010; Tracy, 2010). 
HONORS PROGRAM AT A FAITH-BASED UNIVERSITY

\section{Chapter 2: Literature Review}

\section{Gifted College Students}

Recognition of exceptional abilities and the debates about how best to develop these abilities has not been a uniquely modern or Western phenomenon. For example, in his historical review of gifted education, Tannenbaum (2002) indicated that the great philosophers of Ancient Greece wrestled with these same educational issues. Some leaders, like Plato, proposed special opportunities for those who excelled intellectually and academically, while others petitioned for a universal education system. Neither ideal was ever realized; only those who could afford tutors received any formalized education.

Since that time, educators and researchers have continued to debate whether certain students experience life and learning differently enough from their peers that exceptional educational methods and opportunities should be provided. During the early 1920s, Lewis Terman, Alfred Binet, Karl Pearson, and others extensively studied superior students in terms of intelligence (Eby \& Smutny, 1990). Like most researchers at the time, they believed intelligence was a static trait that individuals inherited genetically. Later, other educational psychologists challenged Terman's deterministic approach to giftedness (Boazman, 2011). They hypothesized that intelligence was a flexible attribute and could be shaped by personal and environmental factors beyond genetics.

Educationally, elementary and secondary schools generally have operated from definitions of giftedness as outlined in federal legislation. The Jacob K. Javits Gifted and Talented Students Education Act was originally instituted in 1965. Congress then updated and reauthorized the Javits Act again in 2001 as part of the No Child Left Behind Act. This legislation has allowed educators to recognize advanced abilities in such areas as 


\section{HONORS PROGRAM AT A FAITH-BASED UNIVERSITY}

intellect, creativity, visual and performing arts, leadership, and psychomotor ability. Additionally, many states have developed their own specific definitions and guidelines for gifted and talented education, leading to significant diversity in who is identified as "gifted" (Mcclain \& Pfeiffer, 2012).

Despite the abundance of work conducted with gifted children and adolescents, less is understood about the experiences of gifted students once they enter post-secondary education. In contrast to methods used in elementary and secondary schools, researchers have not yet developed a robust model for identifying giftedness in adults (Perrone et al., 2010; Ksiazak 2010). As a result, gifted college students are often classified by their participation in an honors program or a similar "above and beyond" college experience. Typically, these types of programs use college entrance test scores as a preliminary qualification for identifying potential applicants (Hébert \& McBee, 2007).

Some researchers have suggested that gifted college students have continued to experience "asynchronous development" in ways that lead to feelings of isolation and misunderstanding (Kem \& Navan, 2006). For instance, Hébert and McBee (2007) provided an extensive look at honors graduates and their reflections on their college experiences. Their research reported themes of past isolation, questioning previous beliefs, and finding support growth within their honors community. These students' experiences indicated that they often did not feel at home or adequately challenged outside of the honors context.

In contrast, research in other contexts has shown that gifted students may not always differ significantly from their peers in terms of experiences, struggles, and needs. For example, Seifert et al. (2007) concluded that, despite some positive development 
HONORS PROGRAM AT A FAITH-BASED UNIVERSITY

among the honors students, these students did not experience any greater degree of "good practices" in education inside or outside the classroom. They hypothesize that perceived differences between honors students and others might simply be the result of conditioning factors from pre-college experiences or from the "gifted student" label, instead of from any genuine asynchrony. Honors students were also not significantly more likely to value the ideals of a liberal arts education over immediate economic and practical needs (Storrs \& Clott, 2008). Furthermore, the expectations of challenging coursework and valuable liberal arts experiences has not been unique to gifted students, but was reported by a majority of freshman students on a previous version of the National Survey of Student Engagement (Gonyea, Kuh, Kinzie, Cruce, \& Nelson-Laird, 2010).

\section{Honors Programs}

Historical Development. Like ancient leaders, administrators in American higher education have frequently wrestled with serving the needs of students they considered “gifted." Prior to 1870 , nearly all institutions followed a liberal arts curriculum based on Protestant Christianity, with a capstone course in "moral philosophy" (Noll, 2006). While some educators attempted to start honors programs at institutions such as Harvard, Princeton, and Yale, they often faced strong opposition because many people believed these types of programs encouraged elitism in contrast to democracy (Dehart, 1993).

Over the next several decades, the United States experienced a variety of cultural and economic shifts that affected the climate of higher education. For instance, an increasing number of university professors were graduating from German universities, which advocated a system of academic and professional specialization (Noll, 2006). Congress also passed the Morrill Land Grant Act of 1862, through which states could 


\section{HONORS PROGRAM AT A FAITH-BASED UNIVERSITY}

establish colleges that would focus more on agricultural and scientific studies and less on the traditional liberal arts. Federal funding for the land-grant schools made them increasingly affordable to students outside the social and financially elite. In a similar fashion, industrial leaders also identified their own potential rewards from higher education. Therefore, they regularly funneled large amounts of capital into a variety of institutions to prepare workers and consumers for their products and services (Altbach et al., 2011).

The response to these cultural and economic factors varied. Many American universities decided to move away from an integrated, one-size-fits-all approach to a more practical, neutral, and individualized approach for higher education. Other schools became more narrow and definitive in their purposes, such as developing into seminaries (Ringenberg, 2006). These structural changes also encouraged the rebirth of honors programs. Wesleyan University and the University of Vermont successfully implemented modified experiences for gifted college students in 1873 and 1888, respectively (Cossentino, 2007). By the 1920s, administrators introduced an honors program at Columbia, followed later by Princeton, Yale, Harvard, Bryn Mawr, Swarthmore, and several state universities. The most successful programs at Swarthmore and Columbia paved the way for programs at many other institutions. Most of these programs focused on a traditional liberal arts curriculum, attempting to combat the fragmentation and specialization of the disciplines in the general curriculum (Carnicom, 2011).

The approach to gifted education entered a period of relative complacency during the mid 1900s until the launch of Sputnik in 1957 (Kitagaki \& Li, 2012). Limited resources following the Great Depression and the perceived success of the United States 


\section{HONORS PROGRAM AT A FAITH-BASED UNIVERSITY}

during World War II diminished the emphasis on gifted education at all levels during the previous decades (Tannenbaum, 2002). The advances in space by the Russians, however, prompted many educators and politicians to conclude that America's educational system was failing to produce graduates adequate for national success. Therefore, with support from new federal legislation, schools initiated or enhanced gifted programs in an attempt to appropriately develop the best and brightest students (Tannenbaum, Kitagaki \& Li). In higher education, both private organizations and the U.S. Office of Education provided grants for the purpose of increasing the opportunities for high-achieving students (Zieniuk, 2012). To this end, Joseph Cohen and several colleagues launched the InterUniversity Committee on the Superior Student (ICSS). Through conferences and information sharing, the ICSS supported the creation and development of many collegiate honors programs. In 1966, the ICSS re-organized into the National Collegiate Honors Council (NCHC) to further support the growing number of honors programs (Andrews, 2011).

Developments in educational psychology brought new approaches to gifted education later in the twentieth century. New learning theories described intelligence as a flexible attribute, shaped at least as much by personal and environmental factors as well as genetics (Anderson, 2003; Tudge \& Scrimsher, 2003). Some of these developments included a growing awareness of Vygotsky's theory of cultural-historical development and the Taxonomy of Educational Objectives. Vygotsky's theory considered the historical and interpersonal elements of human experience as inseparable from an individual's physical and psychological characteristics (Vygotsky, 1934/1986). In the Taxonomy, Bloom and his colleagues outlined several learning categories through which he believed 


\section{HONORS PROGRAM AT A FAITH-BASED UNIVERSITY}

all students could be led to reach certain outcomes (Bloom, 1956). Both of these approaches emphasized the influence of a guide or mentor, whose efforts could further the cognitive development of a student beyond what they might achieve alone. As a result, more educators began to consider intellectual ability as open to development through proper mentoring and encouragement, instead of the innate ability of a small group of students (Mcclain \& Pfeiffer, 2012; Pfeiffer, 2012).

At the college-level, honors programs remained largely unchanged during this time. Resources were more often devoted to the needs of minorities and disabled students as mandated by federal legislation. College students also increasingly distrusted the established authorities of government, academics, and religion. This rejection often conflicted with the classical general education and honors curriculums, which focused mainly on liberal arts subjects from historical and established sources (Tannenbaum, 2002).

The beginning of the new century has brought many new challenges to higher education as well as to honors programs. During the 1990s and early 2000s, attending college became common for most students (American Association of Colleges and Universities, 2002). As a result, colleges and universities attempted to meet the needs of an ever-widening body of enrollees. Many institutions utilized their honors programs, in

part, to respond to these needs (Carnicom, 2011). Through honors programs, colleges and universities could continue accomplishing their missions to serve an increasingly diverse group of students at various levels, while maintaining the degree of challenge and excellence important to gifted students (Floyd \& Holloway, 2006). 
HONORS PROGRAM AT A FAITH-BASED UNIVERSITY

However, honors programs are not the only educational enhancement available for gifted students who seek a non-traditional college experience. Students sometimes shorten their secondary education through early admission to college or participate in dual enrollment during high school (Boazman, 2011; Kronholz, 2011). Other possibilities include graduating early from college, freeing up credits to pursue other interests, and study abroad. These pathways usually involve completion of Advanced Placement or International Baccalaureate courses, and/or adequate scores on accepted standardized tests. These choices have recently become even more attractive to students as education costs continue to rise. In addition, students who utilize these opportunities generally express deep satisfaction with their college experiences (Boazman, 2011).

Program Descriptions. Currently, undergraduate honors programs of various forms can be found in several countries. A recent review of published literature showed that research has been conducted on honors programs in the Australia, Brazil, Canada, China, Great Britain, Malaysia, the Netherlands, and the United States. In 2013, the NCHC listed 1200 member institutions, but since not all institutions with honors programs become members of the NCHC, this represents only some of the programs present in the United States (NCHC, "Join,” 2013, para. 1). According to England's (2010) review of honors programs in America's Northeast, public, four-year institutions were the most likely to offer honors programs. Private institutions offered honors programs to a lesser degree, but were still reasonably well represented in his list. Unfortunately, no one has completed a comprehensive, national survey of honors programs since Long (2002). Therefore, it is difficult to obtain a plenary picture of just how many and what kinds of schools currently offer some type of honors program. 
HONORS PROGRAM AT A FAITH-BASED UNIVERSITY

The multitude of post-secondary institutions and their diverse missions have resulted in a variety of structures for honors programs (Andrews, 2011). Some colleges offer honors programs that exist within a particular department. Other institutions have created honors colleges that are governed by a separate dean, incorporating honors into the residences, financial aid, curriculum, and faculty (Seifert et al., 2007). Whether through colleges or programs, institutions have usually offered one of three honors structures: 1) general honors; 2) departmental honors; or 3) an honors contract (Andrews, 2011; Mosier, 2012). The general honors program has typically emphasizes a more comprehensive educational approach, featuring interdisciplinary topics with greater breadth. Departmental honors offerings have usually focused on advancing the knowledge and skills of students in a particular field, often through independent study with individual faculty. Through the honors contract, students are able to develop their own individual study plans that include a binding contract for completion of the honors certificate.

Even within a similar structure, different colleges and universities have utilized an assortment of pedagogies (Andrews, 2011; Cossentino, 2007). Honors curricula usually fall into one of three categories: honors courses that must be taken in addition to all other graduation requirements, honors courses that replace regular courses, or honors curricula that encompass an entire academic program. Additional or replacement courses can be found in general and departmental honors programs, while the honors contract and some departmental honors typically cover an entire degree or certificate. 
HONORS PROGRAM AT A FAITH-BASED UNIVERSITY

Philosophically, the goals of most honors programs match the essential ideals of a liberal education, as summarized by Mulcahy (2009):

The ideal of the educated person has come to mean a person of intellectual formation, one who possesses knowledge in depth and breadth, one who possesses the knowledge and skills of citizenship, and who is respectful of others and caring toward them, and one who is enabled to engage in thoughtful action. In its assessment recommendations, the NCHC highlights "essential lifelong skills," including thinking critically and holistically, and being able to relate this knowledge to society and humanity at large, as primary outcomes of honors participation (Otero \& Spurrier, 2005, p. 8). However, some honors educators have suggested a need for greater emphasis on the holistic development of their participants (Haynes, 2006; Wawrzynski et al., 2012). In addition, Storrs and Clott (2008) concluded that even honors students were being influenced by the pervasiveness of pragmatic and consumerist approaches to higher education. Only $40 \%$ of the students in their sample were motivated by the "liberal scholar" ideal. An additional 20\% felt conflicted between this ideal and the constraints of the "real world," ultimately making educational decisions on practical benefits instead of personal interests.

Program Context. Psychologists often address cultural contexts when discussing human development. Vygotsky (1934/1986) highlighted the importance of context in his cultural-historical approach to development. He argued that individuals' historical and socio-cultural experiences influenced the processes of their development. Arnett (2011) made analogous claims in explaining his theory of "emerging adulthood" as a distinct developmental stage, which encompasses the typical college attendance period. He 


\section{HONORS PROGRAM AT A FAITH-BASED UNIVERSITY}

asserts that changes in social and economic factors gave rise to this new stage in Western societies, but also have been observed in non-Western societies as they have experienced similar cultural changes. He concludes that the expectations and environments of higher education profoundly affect the transition of these individuals to adulthood.

In light of these theories, researchers have begun investigating many elements of post-secondary institutional contexts. For example, Gonyea et al. (2006) reported that students who attended distinctly liberal arts colleges encountered more experiences considered valuable for becoming a fully educated adult. Barry and Nelson (2005) also observed that students at a religious-affiliated institution achieved a greater sense of reaching adulthood compared to those at a non-religiously-affiliated institution and one that was only marginally affiliated. They noted, however, that the self-selection of student to each institution could have played a part in these differences. A study by Kneipp, Kelly, and Dubois (2011) concurred with this conclusion, reporting that students attending religiously oriented colleges were more "intrinsically religious," and that they tended to flourish in such an environment. On the other hand, Bryant (2011) concluded that academically challenging and culturally diverse exposures during college often resulted in significant personal struggle, which could lead to either positive or negative outcomes.

Like other college students, honors participants do not generally remain isolated from all other aspects of their institutions' campus cultures. Instead they are often encouraged to engage their social and cultural contexts as a purposeful element of their college education. Therefore, researchers have also examined the specific honors communities and the relationships between institutions and their respective honors 


\section{HONORS PROGRAM AT A FAITH-BASED UNIVERSITY}

programs. Regarding the honors community, Wawrzynski et al. (2012) found that those honors students who participated in an intentional "Living and Learning Community," which blended academic and residential contexts, encountered significantly different experiences compared with other honors students and non-honors students. However, differences between the other honors students and non-honors students were not significant. When discussing the effects of an honors program on the wider institution, Cobane (2011) related how the expectations and caliber of university students as a whole changed following the institution's implementation and investment into an honors program. Beginning with honors participants, and then including many non-honors participants, students increasingly applied for and were selected for prestigious national scholarships. He also noted, however, that completing this transition occurred gradually and required the willingness to invest significant resources into the honors program.

Evaluation. The rising costs of education for students and institutions have stimulated a general climate of greater accountability for the resources expended (Snyder \& Carnicom, 2011). More importantly, appropriate and versatile social skills have become increasingly important for achieving success in the more pluralistic, globalized economy (New \& Ghafar, 2012). In response, researchers in the last decade have increasingly focused on assessing the effectiveness of collegiate honors programs. The conclusions from these studies have been mixed, however. For instance, Slavin, Coladarci, and Pratt (2008) quantitatively demonstrated that participation in an honors program encouraged high achieving students to attend a particular college and remain at that same institution following their freshman year. These retention measures remained significant when controlling for non-honors students with similar academic profiles (e.g., 


\section{HONORS PROGRAM AT A FAITH-BASED UNIVERSITY}

SAT scores, GPA, etc.), indicating that the honors program directly affected the results. In contrast, they did not find any correlation with actual graduation from the institution. More recently, Robbins (2010) reported that students completing the honors program under investigation were less likely to graduate in six years than those students who elected to either not complete or not enter the program.

When assessing exposure to good pedagogical practices and learning outcomes, Seifert et al. (2007) demonstrated that honors students displayed some increased cognitive growth, specifically in the areas of reading comprehension, mathematics, and critical thinking. However, the researchers were unable to determine which aspect of the program had influenced this growth, reportedly because it was not a result of any of the components they measured. In addition, they noted that the participants did not indicate any actual significant differences in their experiences, compared with their non-honors counterparts.

Other researchers have used qualitative approaches in order to investigate the affective outcomes for honors students. Honors program alumni from a single university, interviewed by Hébert and McBee (2007), reportedly believed that the honors community presented them with greater academic challenges through the curriculum and peer interaction and more meaningful learning experiences, which encouraged them to be active participants in their education. They remarked that faculty and peers within the honors program respected and challenged them in ways that provided a safe and supportive environment where they could express feelings and work through growth issues in productive ways. Overall, these students believed that they had received an education as exceptional as if they had attended a more prestigious institution. 
HONORS PROGRAM AT A FAITH-BASED UNIVERSITY

Amy Cossentino (2007) described similar perceptions of honors participation by sophomores, juniors, and seniors at four public universities. Participants reportedly experienced a community of scholars who shared their passion for learning and excellence. As a result, they expressed greater satisfaction with their overall college experience. In contrast, experiences in non-honors courses frustrated these same students because they felt the courses lacked meaningful challenge and productive faculty interaction. These descriptions were consistent across all four institutions.

While the results from these studies were generally positive, the researchers have also noted negative perceptions among their study participants. Specifically, Hébert and McBee (2007) reported that the diversity of culture, knowledge, and beliefs challenged the participants' previously held beliefs and values. More recently, participants in a study by Zieniuk (2012) expressed disappointment that they had not achieved as much as they had hoped. They desired a greater focus on diversity and socialization between the honors peers and faculty at their university, indicating that the program was not accomplishing several of its liberal arts educational goals.

In spite of recommendations by the $\mathrm{NCHC}$ to conduct regular program assessment, Bartelds, Drayer, and Wolfensberger (2012) emphasized the minimal data available regarding students' learning outcomes in honors programs. According to the institutions they surveyed, most programs collected data in an attempt to assess their honors programs. They reported, however, that the majority of these evaluated the honors methods and content rather than actual student outcomes. Even fewer demonstrated a connection between the programs' stated missions and their assessments. While a review of published literature can locate numerous reports addressing these concerns for 


\section{HONORS PROGRAM AT A FAITH-BASED UNIVERSITY}

individual institutions, researchers cannot articulate broader generalizations because of the diversity among the honors programs and their host colleges (Mosier, 2012). 
HONORS PROGRAM AT A FAITH-BASED UNIVERSITY

\section{Chapter 3: Methodology}

\section{Purpose}

The purpose of this research study was to better understand the influence of an honors program on students at a faith-based institution. Honors programs have become a typical means of providing differentiated curricula to gifted students in college and universities across the country, including faith-based institutions (Bratt, 2010). However, research remains limited on how students actually respond to these experiences. Research is even less prevalent for students at faith-based institutions, despite evidence that college environments tend to have a significant influence on their students' development (Wawrzynski, Madden, \& Jensen, 2012). Therefore, with the current study I sought to learn more regarding how students at a faith-based institution perceived participation in an honors program influenced their academic, personal, and social development. In order to accomplish the objective, I focused on open-ended, personal interviews with senior honor students at a selective, private, comprehensive university located in the Midwestern United States.

\section{Rational for the Design}

In order to achieve the goal of this study, I implemented a qualitative research design. This method provided better access to rich descriptions of the students' experiences in their own words, and the meaning they ascribe to these experiences (Merriam, 2009). Furthermore, the study emphasized gaining an understanding of the students' experiences in their natural setting, while memories were still fresh to the students, and within the context of their occurrence. This method also allowed for an investigation of the topic in a holistic and integrated fashion, recognizing the 
HONORS PROGRAM AT A FAITH-BASED UNIVERSITY

multiplicity of factors that influence student experiences and the meaning they ascribe to them (Creswell, 2013).

\section{Ethical Considerations}

I followed several procedures to ensure the confidentiality of all participants and handle all personal information appropriately. Students provided their own contact information to me during a presentation to their honors class, and indicated their level of interest in participating. After identifying potential participants, I contacted all the individuals and provided them with a copy of the informed consent form for their review (see Appendix B). I gave students another opportunity to review and sign this form prior to beginning the interview. Participants were aware that interviews would be recorded and that elements of their responses would be used in my thesis. I protected the confidentiality of the participants by 1) maintaining all identifying information in separate files from interview data; 2) keeping all electronic files on a password protected computer; and 3) assigning pseudonyms to each participant for use in the thesis.

\section{Participants}

Research Site. All students who participate in the honors program at this faithbased university completed a relatively selective process to gain admittance. Applicants have scored at least 29 on the ACT or 1290 (composite math and reading) on the SAT, have at least a 3.5 high school GPA, and have been accepted as students by the university (“Honors Program,” 2013). Acceptance to the university further requires articulating a personal faith commitment and signing a community behavior covenant as outlined in the "Admissions Criteria" (2013). At this point in the application process, 
HONORS PROGRAM AT A FAITH-BASED UNIVERSITY

the admissions office informs potential honors students that they are eligible for participation and provides them with promotional literature and directs them to the online honors application. These students must then complete a separate honors application process, which includes writing samples, leadership and service experiences, and extra-curricular activities. From this pool of typically 120 to 160 applicants, only about 40 students are selected each year (Program Director, personal communication, December 15, 2011). In order to complete the honors program, students must then complete two, 5-credit introductory courses during the first year, followed by at least two seminar courses, and finally two 1-credit colloquium courses during the final year. More detailed information regarding the mission, objectives and structure of the honors program is available in Appendices C and D.

Sampling. This study focused on the influence that the honors program had on the students' development during their college experiences at a faith-based institution. Therefore, I limited my potential participants to students in the process of completing the final segment of the honors program. This criterion sampling (Merriam, 2009) provided a more homogenous group from which to better understand the constructs of interest and afforded better access to information-rich cases. The sample also provided an opportunity to understand the honors experience as a whole.

The criteria sampling and purpose of the study limited the size and diversity of the sample. These limitations, according to Kvale and Brinkmann (2009), provided for deeper understanding of the specific constructs being investigated and connecting to the contexts in which they are found. In addition, I could achieve a more detailed understanding of the participants' experiences because the whole group shared many of 
HONORS PROGRAM AT A FAITH-BASED UNIVERSITY

them. Saturation (Rubin \& Rubin, 2011) on several themes occurred within the first wave of interviews with 14 of the participants. The second wave, therefore, utilized more theoretical sampling, focused on gaining an even deeper understanding of these themes within a larger group (King \& Horrocks, 2010).

I began my sampling of participants through an introduction to potential participants by the senior colloquium professor during a class session. At this time, I explained the topic and purpose of my research to the students and allowed them to ask any questions they might have. I gave all potential participants a card to indicate their interest in participating and to provide personal contact information. I personally collected these cards and no other students or professors were aware of the participation level of any student. Participants did not receive any incentive to participate from me or anyone else within the honors program. After this introduction, I contacted all potential participants directly via email in order to set up interviews. I also completed interview verification and follow-up questions through additional email communication. Email was a principal means of communication for all students, faculty, and staff at this institution. Therefore, it was a familiar, readily accessible, and usually preferred, means of contact for the students.

Description. I interviewed 25 individuals out of 31 possible participants; fourteen during a first wave of interviews and 11 during a second wave. Of the 6 who chose not to participate, all of them indicated a lack of available time. Participants' ages ranged from 20 to 22 years. Female students comprised 52\% (13 participants) of the sample and male students comprised 48\% (12 participants). This distribution is very similar to the gender distribution at this specific institution (53\% female, $47 \%$ male) and 
HONORS PROGRAM AT A FAITH-BASED UNIVERSITY

all of the participants were Caucasian: $92 \%$ of students enrolled at the university were Caucasian at the time of data collection. As honors students, these individuals had all met the initial entrance criteria based on standardized test scores. These criteria are typical of students labeled as gifted, and 23 of the 25 students indicated that they had participated in some type of differentiated program for high-achieving students prior to college (Mosier, 2012; Perrone et al., 2010). These programs included AP and honors courses, gifted programs, and dual enrollment in high school and college courses. More information about the participants is available in Appendices E and F.

\section{Data Collection}

Instruments. In-depth interviews with senior honors students comprised the primary instrument for data collection. The interviews followed a semi-structured format, which permitted flexibility during the interview process. This format enabled the participants to highlight areas that were most meaningful to them, and perhaps identify constructs I had not specified (Seidman, 2006). Interviews generally lasted about 30 minutes. Honors students responded to various open-ended questions about their participation in the honors program, backgrounds prior to involvement in the honors program, and experiences at the university in general. I addressed the following constructs during the interviews: (a) personal motivations for attending this particular institution and participating in the honors program; (b) perceived positive and negative elements of the honors program; (c) academic and intellectual influences of participation; (d) social influences of the honors community and activities; (e) spiritual influences of the honors program; (f) comparisons between students' experiences within the program and their college experiences in general; and $(\mathrm{g})$ the perceived role of the 
HONORS PROGRAM AT A FAITH-BASED UNIVERSITY

honors program within the larger institutional context. I based these constructs on the general developmental concepts investigated in the case study of honors graduates by Hébert and McBee (2007). The student interview guides for the first and second cohorts are available in Appendices $\mathrm{G}$ and $\mathrm{H}$, respectively.

Secondary mediums used in the study included 1) classroom observations of the senior colloquium course; 2) reviews of administrative documents for the honors program; and 3) semi-structured interviews with the program director, the senior colloquium professor, and one other participating honors professor who had previously acted as the program director (See Appendices I, J, \& K, respectively, for the interview guides). These interviews lasted approximately 30-40 minutes. I addressed the following constructs during these interviews: (a) perceived positive and negative elements of the honors program; (b) academic and intellectual influences of student participation; (c) social influences of the honors community and activities; (d) spiritual influences of the honors program; (e) historical background of the program's development; (f) mission and objectives of the program and its various components; (g) perceptions of the honors students and their participation in the program; (h) role of the honors program within the larger institutional context; and (i) organizational structure of the program.

Procedure. I collected preliminary information from the university's honors program website, and then obtained administrative documents from the program director in order to obtain a detailed understanding of this particular program. I then observed a typical senior colloquium class, as a non-participant, on two occasions at times pre-arranged with the colloquium professor. After the second observation, I 
HONORS PROGRAM AT A FAITH-BASED UNIVERSITY

presented my research project to the honors students and identified my initial pool of participants. I conducted all interviews in person, at a neutral, but semi-private, location on the campus of the honors program under investigation (King \& Horrocks, 2010). After participants granted permission, I recorded interviews using a digital recorder (MP3 format). During the interviews, I followed a semi-structure interview guide, providing consistency across interviews, but allowing for topics of significance to the individual to emerge within the context of the investigation (King \& Horrocks). The interview data were transcribed at a later time for further analysis. Following transcription and initial scanning of the transcripts, I requested each participant to review and verify their individual transcript and answer some follow-up questions.

The first set of interviews provided a rich source of data and several themes emerged that could be investigated further. Therefore, I conducted a second wave of interviews focused more narrowly on the constructs related to these themes (King \& Horrocks, 2010). For this second group of interviews, I followed the same open-ended, semi-structured format. Pseudonyms were used throughout the thesis to protect the anonymity of the participants and promote reading clarity (Kvale \& Brinkmann, 2009).

\section{Data Analysis}

During the process of analyzing data, I followed inductive coding procedures outlined by Corbin and Strauss (2008) and Miles and Huberman (1994). This inductive process utilized open coding, meaning that certain codes represented concepts unearthed in blocks of raw data, rather than approaching the data with predetermined concepts. I regularly recorded memos throughout the coding process to articulate possible emerging themes and develop connections between the various interview data. 
HONORS PROGRAM AT A FAITH-BASED UNIVERSITY

I transcribed verbatim each student and faculty interview and included notes regarding various non-verbal expressions (Seidman, 2006). I then coded each transcript using a table format described in Miles and Huberman (1994), allowing codes and memos to appear next to their relevant data. Codes represented concepts and their properties as they were discovered in the data (See Appendix L for a complete list of codes). I sometimes combined or collapsed codes and concepts as the data warranted. These concepts developed into the emergent themes, which either coincided with the focus of interview questions or introduced previously unaddressed constructs. These themes supplied the basis for the second wave of interviews. I then repeated the analysis process for the additional interviews. I compared all other data, including observation notes and program documents, to the codes and themes from interviews.

\section{Researcher Reflexivity}

As the sole researcher for this study, I conducted all phases of data collection and analysis alone. As such, my role and perspectives cannot be fully extracted from the interpretations of the data and should be clarified (Creswell, 2013). I have had previous personal experience with both this honors program and its faculty as a former honors student. Unlike the participants, however, I did not complete the full sequence of the program, nor have I had direct contact with elements of the program for over ten years prior to beginning this study. This past connection was revealed to the participants during my initial presentation in order to build a sense of rapport. However, I provided no other details of my personal honors experience prior to individual interviews in order to help reduce the chances that my experiences might potentially influence the responses of the participants and they would reflect primarily on their own experiences. 
HONORS PROGRAM AT A FAITH-BASED UNIVERSITY

\section{Validity and Reliability}

When addressing the issues of validity and reliability, I employed several methods during data collection and analysis in order to ensure the rigor of this research study. I used the following procedures to support internal validity: triangulation, member checks, low-inference descriptors, a thorough data trail, researcher reflexivity, and review of the project by an independent expert in qualitative research. In order to enhance external validity, I employed the methods of gathering thick, rich descriptions and interviewing multiple independent cohorts of the program I investigated. These procedures also benefitted the reliability of this investigation. These procedures are described in more detail in the following paragraphs.

Regarding internal validity, I employed several methods to ensure that the data and conclusions adequately reflect the genuine observations and perceptions of the participants. I began by using the process of triangulation in order to become more immersed within the actual lived experiences of the participants (Creswell, 2013). I completed interviews of honors program professors who interacted regularly with these students, observed actual class interactions, and reviewed primary program documents. These contributions helped to develop a clearer picture of the context through which the participants' experiences could be best understood. In order to diminish the possibility of misinterpreting the interview data, I employed member checks at multiple levels (Mero-Jaffe, 2011). I requested all participants to verify their respective transcripts and indicate any corrections or clarifications. Three participants did not respond to this request for verification and all further attempts to contact these individuals were unsuccessful. I also provided the results to a sample of the participants and asked them 
HONORS PROGRAM AT A FAITH-BASED UNIVERSITY

to verify their general agreement with the themes presented. The results were compiled using both low-inference descriptors and direct quotations from the interviews (Chenail, 2012; Merriam, 2009). Furthermore, the quotations I included were both broad and deep, in order to allow the participants' words to speak for themselves in supporting the emergent themes. Additionally, by maintaining a comprehensive data trail, I provided a thorough audit of the entire research process. This included maintaining records of the data analysis codes utilized and compiling extensive lists of participants' quotes that supported each theme (Rogers, 2008). I also presented each element of this research project to an independent expert in qualitative methodology for review. The expert assessed the thoroughness of the qualitative research process and examined the data results and data trail to ensure that the participants' sentiments were reasonably represented. Finally, I reflected and clarified any areas of potential bias on my part as the researcher. I included this reflection early in this paper so that the readers had this information available throughout their review of the study.

External validity addressed the ability of results to be generalized to additional situations (Merriam, 2009). To this end, I accessed participants who provided information-rich data and facilitated reaching the saturation point regarding relevant themes through both purposeful criteria sampling and theoretical sampling (King \& Horrocks, 2010, Rubin \& Rubin, 2011). I also conducted a second wave of interviews, which involved a separate cohort of students after the previous cohort had graduated. The presence of variations between these two groups strengthens the credibility of those themes that appeared consistently between both set of participants (Patton, 2002). 
HONORS PROGRAM AT A FAITH-BASED UNIVERSITY

Given the rigorous methodology (Sin, 2010; Tracy, 2010) utilized in the present study, the results have some reasonable level of external validity that can be applied to other honors programs. In particular, programs that share demographics with the present sample can make some reasonable generalizations from this study's findings. In qualitative research, replication is the ultimate mean of establishing external validity. Consequently, as future researchers repeat this study under varying samples, the present results can be placed into a larger context with external validity level being clearly seen.

For qualitative research, reliability centers on the ability for future researchers to replicate the study (Merriam, 2009). I audio recorded interviews to capture the exact expressions of the participants, including tone, pauses, and unique verbal mannerisms. I also kept detailed observation notes and maintained organized computer and paper files to ensure a data trail of evidence. Finally, a review of both results and method by the expert in qualitative research methodology ensured that the present thesis followed rigorous and appropriate qualitative methods (Sin, 2010; Tracy, 2010). 
HONORS PROGRAM AT A FAITH-BASED UNIVERSITY

\section{Chapter 4: Results}

\section{Introduction}

The participants in this study were all senior students completing the final course within the university's honors program. They came to this university from a wide variety of educational, geographic, and personal backgrounds. Some students had been investigating elite universities, while others had several family members attend this same school. They had varied pre-college experiences from growing up internationally to living in a small community of around 500 individuals. Nearly all of the students had participated in some type of gifted or advanced curriculum during their elementary and secondary education. In a similar fashion, at college, the majority of the participants were completing additional majors or minors in conjunction with their primary degree, the required Bible minor, and the honors program requirements. They represented a broad cross-section of academic departments, including both liberal arts programs and professional programs.

The majority of participants indicated that they purposefully had selected the religious and social context of this rural, faith-based university, compared to the other schools they had considered, even though their incoming academic credentials afforded them desirable alternatives. They were also attracted to the perceived institutional commitment to academic quality. Furthermore, every student indicated that the honors program was one of the most valuable experiences they had during college. The qualitative, phenomenological interviews with the honors students provided an opportunity to better understand what experiences these students found to be most meaningful and reasons for them believing this to be the case. Four primary themes 
HONORS PROGRAM AT A FAITH-BASED UNIVERSITY

emerged from their responses. First, the students emphasized the integrated nature of the honors program, including an interdisciplinary foundation, authentic life integration, and a pursuit of excellence. Second, they valued the intentional self-authorship that occurred as part of their experiences, such as being encouraged to clarify their own worldviews and the parallel development of humility and confidence. However, they also wrestled with tensions that resulted from unresolved questions. Third, the students were impressed by the purposeful exposure they encountered through the novelty and variety of the content as well as the diversity of the individuals within the program. Finally, these students appreciated the sense of fraternity they developed within the program. They expressed this appreciation regarding their own respective identities as honors students, the community of learners, the prudent freedom provided, and the connection to the rest of the university (even though the latter also involved some dissonance at times).

\section{Integration}

Effectiveness in the interdisciplinary curriculum. All of the participants described the honors program as being authentically integrated: connecting multiple elements of human existence in the learning process. The freshman sequence, titled Making of the Modern Mind (MoMM), was said to have had the most profound effects in this area. This course connected the subjects of philosophy, history, and the humanities together while covering the development of Western civilization from ancient times to the present. The students indicated that this interdisciplinary format allowed them to comprehend the knowledge presented in more comprehensive and effective ways. This interdependent understanding created a foundation and framework for the subsequent knowledge and learning they encountered in college and beyond. The students frequently 


\section{HONORS PROGRAM AT A FAITH-BASED UNIVERSITY}

emphasized that the knowledge gained through this initial year was applicable for them, regardless of their program of study. For example, Devon illustrated this point when he stated:

The honors program has done a great job of showing how interconnected all of knowledge is, and by highlighting the ways in which this interconnectivity works. It has helped me be able to create a holistic "worldview" which allows me to critically analyze both my theology and the way I approach medicine, my chosen field of study.

The students also said this foundation helped them later, particularly in the more specialized honors seminars, because they did not have to spend time reviewing the contextual knowledge of each new subject. Therefore, they could study a broader range of topics, such as bioethics, postmodernism, and feminism, with more depth.

In addition to the educational benefits, the participants remarked that fields in the liberal arts, such as philosophy and art, acquired greater value for many of the students. By learning about art forms within the context of their creation, they could better understand pieces that had previously held relatively little importance to them. The students pointed out that these exposures did not radically change their personal preferences, but rather enhanced their ability to find meaning, beauty, and enjoyment in subjects that many would have otherwise ignored. For example, Neil expressed the sentiment this way: "I think it has allowed me to see that there are other components to academia, to learning, to life that I enjoy." Dustin explained further by saying: "Having multiple fields involved helps because you naturally see how they interact with each 
HONORS PROGRAM AT A FAITH-BASED UNIVERSITY

other. Thus, a subject which might be less appealing becomes more important to the student when he can see the impact it has on other fields."

Overall, the students judged that the interdisciplinary curricula had the most lasting effects on their academic development. It built a philosophical and historical framework through which they could organize and connect various other educational experiences. However, they also identified components of the program that they desired to see strengthened. Several participants commented that the seminars and senior colloquia seemed less coherent than the MoMM sequence. They described these components as interesting, but felt less certain of the objectives. Despite some evident disappointment in this area, the students expressed overall confidence that completing the honors program had more effectively prepared them for the rest of their college and postgraduate experiences.

Experiencing life integration. The honors program was said to have gone beyond just the integration of disciplines, however. It evidently demonstrated an approach to living life in an integrated fashion, and encouraged students to do the same, on a routine, daily basis. According to the students, integration in this context meant taking the knowledge they had acquired in the classroom out into their everyday lives. They also connected their education to daily decision-making, allowing the results of those interactions to influence how they lived life. For most of the students, this process was said to have occurred implicitly through contact with the honors professors. The faculty brought their own experiences into the content and related how the discussed theological or philosophical ideas affected practical life. Although the students admitted that they could not adequately articulate a formal definition of integration, they believed 


\section{HONORS PROGRAM AT A FAITH-BASED UNIVERSITY}

they witnessed and learned it through their professors' examples. Seth provided an example of this type of learning from the "coffee talks" sponsored by the honors student organization. He described how two honors instructors presented arguments for their decisions during the presidential election season: "It was one of the best discussions I've ever experienced because they're both really knowledgeable and they have amazing reasons for what they're doing, and they were super respectful of each other and then all of us asking the questions."

The course content also was said to have influenced the honors students' perceptions about their own respective abilities to integrate their lives. The honors program evidently challenged them to move beyond simple facts and to explore presuppositions behind various historical events, religious movements, philosophies, and art forms. The participants consistently described this process as a primary element in developing their critical thinking skills. Kylie explained:

You take that unconscious act of integrating your faith into your actions, and your decisions, and into life. You make that a conscious action, which I think makes a huge difference, because then you start evaluating your decisions, not only through that initial lens, but also through the lens of looking at your lens.

Through the honors courses, the students communicated that they had gained a more sophisticated understanding of their historical foundations theologically and philosophically, and could more clearly envision moving forward in the future. As a result, participants stated that they better comprehended where they fit within their respective belief systems or where subsequent change was needed in order to better fit within them. For some, this process entailed adjusting various life paradigms. For others, 


\section{HONORS PROGRAM AT A FAITH-BASED UNIVERSITY}

this meant adjusting their actions to be more consistent with what they believed. They described the process as learning a new way to learn and live within the context of a new way to interact with others and with ideas. One poignant example of this dynamic, similar to the sentiments of most participants, was Hillary's recollection:

I remember freshman year. I bought coffee all the time, and I spent probably 30 bucks a month on coffee. And I remember sitting in that class and just being, “There's 30 dollars of me just contributing to this whole materialistic mindset." And I remember I was just very frustrated with myself. So...I just stopped buying coffee, and I ended up adopting a little girl from South Africa, and taking all that money that I would've spent doing something like that and putting it in a different place, in a place where the gospel would have an opportunity to impact her life through that giving.

Pursuing excellence as a way of life. Similar to integration, the students participating in the honors program reported that they were challenged to pursue excellence. Integration of all areas of life comprised one aspect of excellence for these students. Additionally, they defined excellence as being fully educated, in contrast to merely acquiring a degree. While the students valued the pragmatic benefits of the honors program (e.g., scholarships and an enhanced academic profile), they tended to speak with more satisfaction about the educational growth they experienced. As Esther articulated: “You aren't just learning facts for a degree anymore. You aren't focused on checking off courses so you can get a job. You're concerned about being educated, about learning, about exploring ideas and applying them, not just to a career, but to life." 
HONORS PROGRAM AT A FAITH-BASED UNIVERSITY

This dedication to pursuing excellence in academics evidently came somewhat naturally to these students. They routinely remarked regarding the enjoyment and fulfillment they experienced through participation in the program. For example, Karen described the honors students generally as people who "genuinely wanted to learn about what we were learning. And we would even do things that were extra or outside of the class because they sounded interesting or enjoyable to us." Several other participants reinforced this portrayal through their own instances of independent exploration on theological and philosophical topics. They appreciated being challenged and allowed to think at higher levels within the honors program courses. When recalling instances within the program that urged them beyond their typical limits, the students expressed how much they valued the academic growth that resulted. Esther voiced this consensus by saying: "I love those classes, not because I particularly love, you know, huge workloads and strict professors, but because I know that we're held to a standard of excellence." In summary, the honors students at this university were said to have been intrinsically motivated to become well educated. Additionally, the honors program was said to have stimulated them to excel further, which the participants believed would prepare them better for future achievements.

\section{Intentional Self-Authorship}

Encouraged to personally own their beliefs. As an inherent part of the integration process, the honors students engaged in self-authorship. This construct is considered to be a primary factor in identity formation, involving questioning one's beliefs and values and those of others in order to better understand and commit to or reject them (Mayhew \& Bryant, 2013). The students related that encouragement in self- 


\section{HONORS PROGRAM AT A FAITH-BASED UNIVERSITY}

authorship provoked frequent struggles and discussions many of them had never previously experienced. The honors courses deliberately required them to grapple with foundational propositions of theology, philosophy, and ethics through class discussions or written papers. The honors students acknowledged the difficulty of this process, sometimes using terms such as "unsettling" and "disturbed." They found it particularly difficult because the professors urged them to reach their own conclusions, instead of directing them to one position or another. To illustrate this point, Cassie said, "It forces you to think, and think for yourself, and not just parrot ideas."

Challenging as it was, participants all attested to profiting from this process in their academic, social, and spiritual development. Serious evaluation and investigation evidently came naturally to these students, as Heather remarked: "I remember in high school, I've always actually really liked talking about theological and philosophical issues." Furthermore, Jackson observed: "I tend to be an intellectual person and want to really think through and know things deeply and understand my faith on a real level and not just on a surface level." At the same time, the honors experiences were said to have presented them with additional opportunities to intellectually analyze and understand their respective worldviews. The students believed that their respective experiences helped them achieve greater maturity earlier in their college experiences instead of later as compared to their peers. For example, Jeff described the honors sequence as a process that "catalyzes the learning process at a higher rate than the students around you." By doing so, the students said that they could better harmonize their intellect and their faith, allowing them to develop a more coherent personal identity. Erica summarized this conclusion through the following statement: "I know I've grown a lot since freshman 


\section{HONORS PROGRAM AT A FAITH-BASED UNIVERSITY}

year, and it's gone from being these are my parents' beliefs, to these are my community's beliefs, to these are actually my beliefs."

The students also mentioned other aspects of their identities that they came to affirm through the program, ranging from career choices to personality traits. They related having discovered new avenues of intellectual interest and acceptance, despite differences. These discoveries were said to have encouraged the students to value their own identities, separate from friends and authorities. Kathy captured these experiences in her interview that summarized the sentiments of most participants:

I know I'm not a sensitive person, but I think I'm at least more aware of the fact that I'm not sensitive, and able to compensate for that....I think the honors program gave me confidence that that was okay, that even if I didn't agree with someone, or didn't even agree with the professors who have, you know, $\mathrm{PhDs}$ in theology, that doesn't mean that I'm sinning or, or making a mistake, it's just my convictions are different."

Developing humility and confidence. The study's participants indicated that, through exploring their beliefs and identities, as well as those of others, the honors program simultaneously fostered humility and confidence. When reflecting on their freshman experiences, the students felt more competent regarding their potential achievements and engagement with life and culture. Esther verbalized this belief when explaining:

It gives you confidence that you at least are prepared to ask the right questions. You are prepared to encounter any situation and think about it correctly, or at least start thinking about it correctly. And I think that confidence is very 
HONORS PROGRAM AT A FAITH-BASED UNIVERSITY

beneficial in deciding, "Okay, you know, can I do this? Can I go and make a difference, and be successful in any field I choose to enter?"

The students credited the program with developing their academic and intellectual skills. As freshman, they were required to generate reading summaries and to articulate, within 1200 words, their respective positions on fundamental theological debates such as predestination vs. free will. The other seminars and colloquia continued these patterns through course discussions and papers. As a result, they felt better prepared for the graduate degrees or careers they intended to pursue, as well as the complexities of adult life. Specifically, Jeff noted:

Seeing my ability to succeed in writing and thinking has, more or less, solidified my desire to pursue law as a career. But I think confidence in general kind of fosters a mentality that is just very helpful in academic lifestyle. That doesn't have to be even in the classroom, just the way that you carry yourself. Concurrently, the students spoke in terms of being humbled by the "grand scheme" view of reality and theology that they experienced in the honors program. Through their academic experiences, they encountered several competing arguments in metaphysics, epistemology, theology, politics, and ethics. Participants mentioned how they came to see that philosophical positions which some might have been advertised as new in society were actually recycled versions of older philosophies. They also frequently remarked about being introduced to a broader view of Christianity than they previously had considered before attending college. Drew fittingly described the group's feelings: 
HONORS PROGRAM AT A FAITH-BASED UNIVERSITY

It showed me how much this has been a struggle that's been going on for centuries and I'm not going to just come in and discover the answer...but not giving up and still wrestling with it to come to a deeper appreciation of God and even just realizing how incomprehensible $\mathrm{He}$ is.

This humility most often was said to have led the honors students to respond more charitably towards the views of other people who might disagree with them. The constant dialogue evidently prompted them to contend with the tension between appreciating a person and yet disagreeing with that person's ideas. Participants also spoke of content that pushed them to confront their own misconceptions and misunderstandings at times. These experiences were said to have encouraged them to learn from one another in addition to learning how to disagree in respectful and profitable ways. Like the other students, Natalie noted that her honors experiences challenged her "to be more open minded and willing to listen, not necessarily to change what I think, but being willing to listen to what other people have to say."

Addressing unresolved questions. Despite the assurances of confidence, participants indicated that the emphasis on self-authorship left them with some reservations about the approach. Students shared the opinion that the honors coursesespecially the freshman year - prompted them, or others, to finish college with "more questions than answers." The students recognized that the purpose of the program was to challenge them academically and encourage them toward articulating their own worldview. However, they also expressed concerns that the process was too open ended. Indicative of many students' comments, Jackson stated: 
HONORS PROGRAM AT A FAITH-BASED UNIVERSITY

I think for some people throughout the program, it forces people to question their faith to the point of...I guess, providing too many questions to where they begin to doubt their faith more than they get answers for their faith. For me, I wouldn't say it's done that, but I've definitely seen that happen in the program.

Similarly, Kylie concluded:

It can lead astray sometimes, because you don't ever really reach a conclusion, which is almost sometimes worse than even not broaching the topic. While I find the honors program really good and challenging...for me, it's made me a bit less childlike in my faith, and kind of more cynical and analytical.

To resolve these concerns, students suggested that the honors professors either revisit the weighty freshman year topics in order to provide some closure or to contribute more personal insights and foundational determinations. They valued the opportunities to think for themselves but, as Jeff admitted, "It would be good to have a more clear theological basis, I think, at times in the program, where students have a more obvious and overt understanding of what is good, what is right, what is true in theology." All the students struggled somewhat when addressing this area, because they felt they could not adequately resolve the tension between desires for freedom and security. Matt demonstrated this tension with the following comment:

I think one weakness, which would be inherent to the benefit, would be with better critical thinking it can easily be taken to an extreme. So to the extent that we might critique a lot of things, but maybe...not always, or depending on the extreme, never, provide any answers or any solutions to what we're constantly raising. I think that can have some negative effects. 
HONORS PROGRAM AT A FAITH-BASED UNIVERSITY

\section{Purposeful Exposure}

Encountering variety and novelty in the content. The participants in this study indicated that integration and self-authorship most often resulted from encountering the broad variety of and unfamiliarity with the honors content. They prized the broader range of intellectual, artistic, and interpersonal experiences that came with the honors program. This variety was the primary feature that initially drew the students to the program. They described it as having been an opportunity to "take a break" from their discipline or use their brains in different ways. Even though the honors students desired and enjoyed variety and challenge, they confessed that they probably would not have ventured much outside their respective disciplines and personal preferences if they had not participated in the honors program. For instance, Patrick remarked: 'I don't think I would really have any interest in doing those, if I hadn't been in the honors program and hadn't been exposed to some of these other ways of thinking about things." Thus, overall, the students perceived that this content played a significant role in broadening their educational experiences in college.

The honors program also was said to have afforded students with the opportunity to tangibly encounter subjects being studied, as opposed to just reading about them or hearing a lecture. This was especially true for the honors seminars. Examples included traveling abroad to Ireland, Greece, France, Oxford, or more local experiences such as camping overnight when studying nature literature and developing policy suggestions for the university during a creativity seminar. Dustin's thoughts best illustrated this esteem for experiential learning: 
HONORS PROGRAM AT A FAITH-BASED UNIVERSITY

If I had done that class and we didn't go over and, you know, watch and listen to [the professor] play music and explain everything as he was doing it, I would still not know a thing about romantic music. Let's be honest, I would be like, "Well I learned some cool words and I know that Schubert was involved at some point." And that's not knowledge, that's Wikipedia.

Conversely, the students were often challenged by their unfamiliarity with the content. Not only did the honors program help them to know more information, but it was also said to have demonstrated to the students how much they did not know, and might never know. Jackson characterized the program as having presented "so many ideas that I never thought of or never really considered. It really expanded my worldview and really forced me to think about things from different perspectives, rather than the one perspective that I had always been taught." In response, many of the students expressed a desire to revisit the honors content again because they could retain more information after having an apt foundation on which to build their knowledge. They considered having been confronted by the unknown as a significant catalyst for much of their questing.

Encountering diversity within the program. The broad content was not the only aspect of the honors program that moved the students outside their comfort zones. They also expressed appreciation for the diversity among the other students and professors. In their opinion, the program brought together an assortment of people that they could not otherwise have experienced in any other venue on this campus. They surmised that this diversity might have occurred through some of the ministry avenues, but not likely to have produced the deep philosophical and theological questioning that they experienced through the honors program. Neil expressed this sentiment when he observed: 


\section{HONORS PROGRAM AT A FAITH-BASED UNIVERSITY}

"The honors program has allowed me to meet people from multiple different backgrounds, to really cross disciplines, and to be able to speak and converse on topics of weight."

Likewise, the honors students felt that the diversity of perspectives contributed further to their humility and genuine learning. The dialogues both in class and in cocurricular activities forced them to reconcile intellectual disagreement with valuing and enjoying the individual. This was especially true when the expressed opinions and backgrounds contrasted with those typical of the general student body. For instance, Patrick related:

Having people who are thinking critically and really engaging ideas. Interacting with them is probably the biggest way [the honors program changed me socially], because when you are having, really deep, thoughtful conversations with people that you disagree with, or with people who are coming from very different backgrounds, then that sort of teaches in a lot of ways how to interact with them. Therefore, the students accredited these exposures with teaching them to respectfully engage culture and individuals on a broad scale.

\section{A Sense of Fraternity}

According to the honors students' descriptions, the diverse and dialoguing community was the most defining aspect of the honors program. It naturally developed a sense of fraternity among the students. According to the Oxford English Dictionary (2013), the word fraternity means "a group of people sharing a common profession or interests; and a state or feeling of friendship and mutual support within a group." This 
HONORS PROGRAM AT A FAITH-BASED UNIVERSITY

construct is more thoroughly understood through the honors students' common identity, the community of learners, and their connection to the wider university.

Sharing a common identity. Despite the diversity that the students observed within the honors program, the participants also exhibited a number of similarities. Many students categorized themselves as having been the "smart kids" in high school. They applied to the honors program partly because of this self-identification. As Dawn remarked, "I was always an honor student growing up, so it just kind of made sense to apply and see." The students also said that their similarities fostered an enjoyment of the learning experiences in contrast to a competitive spirit focused on performance, as Michaela related: "When other people show an interest in learning it is infectious." Several participants mentioned that they reorganized their priorities to include relationships and fun instead of just academic study. For example, Neil stated: “They've convinced me that it is important to do well but, at the same time, to not take it so seriously that you can't think of anything else."

Experiences enhanced by the community of learners. Possessing a common identity was reported to have eventually transformed the honors students from a group of unknown freshmen and professors into a supportive intellectual community of learners. Initially, the participants reportedly did not recognize this connected identity. For instance, Kylie reflected on her experiences, commenting: "I felt so confused and lost... Now I realize that everyone else was feeling the same way, but we didn't know it at the time." Cassie also articulated this feeling when she remarked: "That first week was like, 'All these people are so smart. I can't fit in.' And it didn't feel safe the first week. But then after really getting to know them...this really is a safe [group].” The students 


\section{HONORS PROGRAM AT A FAITH-BASED UNIVERSITY}

reasoned, however, that they could not help but to have developed these types of relationships within the structure and content of the Making of the Modern Mind (MoMM) curricular sequence. In this course sequence, they attended class for 50 minutes every Monday through Friday for a full year.

Participants also believed that addressing so many weighty issues formed a common understanding and bond that could typically have been shared only with other honors students. They even connected with other honors cohorts because of the consistency of MoMM experiences and other honors extra-curricular activities. Erica's comments articulated this shared sentiment:

I'd say the camaraderie between the people in this program is completely different from any of my other friendships just because we've all got such a weird perspective compared to the general population, even at [this university]. We're willing to discuss in completely different directions that normal groups wouldn't. Alternatively, the more substantial feelings of fraternity generally existed only between students within a single MoMM cohort. This constraint resulted from each class developing its own "personality." Esther recalled:

At least from what I heard, the earlier class, the class before me, had a much more contentious personality. But in my class, we were just, I think, a particularly easygoing group. It felt more like a dialogue, but in a more collective fashion.

The variations in class "personality" were also noted through direct observations prior to interviews. The conversations and actions within the classroom were more relaxed and jovial than the previous cohort. The descriptions of relationships between classmates corroborated these observations, indicating that the first cohort connected primarily on 
HONORS PROGRAM AT A FAITH-BASED UNIVERSITY

the academic and intellectual levels, whereas the second cohort connected more on the social level, in addition to the academic and intellectual.

Despite these differences, the overall learning community offered the honors students a sense of fraternity because they felt comfortable about their own identity within this group. They considered the program as their best potential resource for profound conversations that ranged across various academic topics. Devon depicted this perspective when he observed: "The honors program definitely did help me get plugged in with people who shared my fondness for discussing things beyond the superficial level." Moreover, the participants considered this community to benefit them developmentally. As related in previous themes, the program prompted significant struggle within the students. However, they communicated that the honors community also contributed some support and security that they evidently needed in order to face those struggles. Matt summarized these feelings by saying: "Others who are there with you are willing to work and struggle to understand the issues and the concepts, and that fellowship and mutual strengthening/encouragement is very conducive to learning and creating an environment in which to learn."

Finding safety in an environment of prudent freedom. When discussing the honors program community, the students' comments regularly focused on it as having been a relatively safe place. The freedom they experienced evidently allowed them to genuinely investigate other perspectives, beyond those to which they had been exposed in their personal backgrounds, and even those different from the beliefs of the university they attended. Many students perceived that other classes at the institution were taught with very specific perspectives or underlying assumptions with which students were 


\section{HONORS PROGRAM AT A FAITH-BASED UNIVERSITY}

expected to agree. Within the honors program, however, students believed they could question those assumptions, genuinely analyze them, and arrive at their own conclusion about foundational issues. As Jacob stated:

You can bring up hard questions, maybe even some things that Christians think that they maybe shouldn't be asking or something like that and really debate them seriously. So, I would say, yeah, it's safe to really talk about things that you're struggling with maybe, and you're saying, "This doesn't seem to make sense with my faith. How do I reconcile those two things?" And so it's always been a safe place for say, "Well, here's what these people say..." and you can really get some real help to understand where you are.

The honors students also expressed a sense of freedom within the community because of the mutual support among their peers. To the participants in this study, the honors program provided them with a place where they were not subject to judgment or ridicule, even when their beliefs and perspectives conflicted. Erica described this more definitely saying:

You can basically put your beliefs out there and defend them philosophically and other people would attack it from different viewpoints, but it's all more of an intellectual argument. And at the end of the day you know you're still going to be friends with this person, even if you actually do wind up completely disagreeing on that topic.

As a result, the honors students spoke in terms of having felt free to learn and grow together, not just at the same time, but also as a collective body. They credited this 


\section{HONORS PROGRAM AT A FAITH-BASED UNIVERSITY}

freedom with having added a community element to their spiritual development that had not been as prevalent before.

In association with this freedom, the honors students also characterized the environment as prudent, or "marked by wisdom and judiciousness" (Merriam-Webster Dictionary, 2013). Although the program forced the students to grapple with difficult issues and analyze several of the beliefs that comprised the foundation of their faith, they also affirmed that the process did not feel threatening. Instead, they felt that the honors program provided a solid biblical context for framing the worldview they would adopt as their own. Even those students who were concerned by unresolved questions did not feel that the honors program encouraged a rejection of their faith, but challenged them to honestly evaluate their beliefs and to establish what they truly believed. Jackson conveyed the typical perception of participants through his evaluation:

I think it's really forced me to be honest with myself in raising questions and maybe not providing all the answers, but learning what I can accept on faith and what we can find in Scripture versus what we might not ever know.

As stated earlier, students said that they felt encouraged to pursue a genuinely integrated life in which their verbalized values corresponded to their actualized values. Ultimately, they concluded that this balance between the prudent environment and the freedom to explore correlated directly with the beneficial outcomes they experienced. For example, Natalie expressed the general consensus when she stated:

Now that I'm considering graduate school, I've been looking at bigger schools that are going to have a lot of challenging ideas to my own, but that this has prepared me in a safe environment to consider different thoughts and kind of 
HONORS PROGRAM AT A FAITH-BASED UNIVERSITY

return to what I believed and not gone off and started doing other things or a harmful lifestyle.

Professors as more than scholarly instructors. The professors also played an important role in the honors community. Jeff articulated this when he stated: "I find the quality of professors to very high, very interested in students, very interested in learning. I think that's the case in the institution as a whole." As conveyed in Jeff's statement, the participants viewed the honors professors as comparable to most other professors at the university, but suggested that the honors program encouraged increased interaction with them. They claimed that the smaller classes and discussion format of the honors courses provided students with opportunities to engage the professors on more personal levels. Additionally, the participants described the honors faculty as having been receptive to questions, discussions, and even "intrusions" into their personal time. When describing the honors director, for instance, Megan illustrated this feeling: "You know that you can ask him anything and he will give you a very educated, very considerate, very honest response." Karen added the impression this connection left on the students:

The professors were all very different, but typically all very interested in connecting with you on a personal level. And I think that if they make the effort to do that...it kind of takes your desire to learn from them to sort of a whole new level, because you know that this isn't just their job. It's something that they believe in and care about.

The participants sensed that the professors did not desire to handicap students' GPAs for participating in the honors program, but maintained high expectations for their performance. Faculty reportedly communicated their expectations more by anticipating 
HONORS PROGRAM AT A FAITH-BASED UNIVERSITY

that the students would come to classes knowledgeable about the topic of the day and prepared to engage with it. Likewise, they did not view the professors as "masters," disseminating information from a grand pedestal, but rather as partners in their intellectual and spiritual journeys. The students often related how professors made themselves readily available and engaged with the members as individuals. Dustin's story illustrated how relationships with the honors professors significantly influenced the honors students' college experiences. He recounted that he struggled adjusting to the rigor of college his freshman year and likely should not have been able to continue in the program. His discouragement was so pervasive that he even questioned whether or not he should continue to pursue a university degree. However, Dustin continued:

Dr. Morris recognized a kid who was struggling to get on his feet, and he went out of his way to bend the requirements and give me a second chance when I really needed one. And even after it had all happened, it did provide some great motivation to improve. Wanting to get good grades is great, but to know that you've got the prof believing in you makes all the difference.

A discrepant relationship with the wider university. The honors students provided positive and negative evaluations regarding their relationships beyond the honors program. This program offered very few "perks" to participants, limiting those advantages to potential scholarships, graduation recognitions, and shared access to a designated classroom. Therefore, these students did not perceive that the program promoted elitism or exclusiveness. In fact, most students described the honors program to simply have been an additional minor added to their regular studies. Esther spoke for most of the participants in this regard when she said: 
HONORS PROGRAM AT A FAITH-BASED UNIVERSITY

I like that the honors program isn't too different, that you can sort of add it on as a minor, and it doesn't transform your whole curriculum, and it doesn't make you, you know, one of "those people." Most of the honors students have many of their close friends outside of the program, and they attend classes with many nonhonors students.

Furthermore, the students generally considered the majority of the university's students to be equally capable, intelligent, and enjoyable. Most of them engaged with peers outside the program through various extra-curricular activities and ministries at the university or in the local community. Several of the participants also noted that honors students frequently filled various leadership positions within these groups.

Nevertheless, participants also encountered some awkwardness and misconceptions about the honors program or its members. The honors members felt particularly distressed talking about the program with non-honors students because such conversations sometimes suggested inaccurate distinctions between those who participated and those who did not. However, they also remarked that their experiences in the honors program changed them in ways that made interacting with the other students somewhat awkward at times. Hillary’s statement captured this sentiment:

In some ways being in the honors program has made it more difficult, I would say. Just because that whole comprehensive course, especially your first year... It just teaches you to think a different way. A lot of students who haven't, I guess, had the opportunity to learn to think like that, often don't. So sometimes they don't understand when you don't want to do something or when you think something is wrong. 


\section{HONORS PROGRAM AT A FAITH-BASED UNIVERSITY}

Individuals outside the program also sometimes communicated negative perceptions to honor students. As an example, Daryl recalled: "From my interactions with others, students don't normally seem to have high opinions of a lot of honors students as they claim that honors students act like they are better than everyone else." In addition, participants indicated that sometimes honors students had been stereotyped as being arrogant, politically and theologically liberal people who did not correspond to the rest of the university community. For example, Michaela explained:

I just know that some [past honors members] have been outspoken about their ideas, which I think is totally fine, they're entitled to their opinion, but I think just, you know, the law of the few sort of dictates that idea of the many. Devon added: "Looking back at some of the controversies over my time here, a lot of them were spearheaded and/or propagated by students who had been involved in the honors program." Other comments from both student and faculty interviews indicated that "superior attitudes" were also sometimes a problem within the honors community,

primarily among freshman. They expressed the belief that these attitudes usually diminished as students matured. In response to these negative experiences, the participants stated their desires to increase the connection between the honors program and the broader university community. They felt that the lack of knowledge sometimes contributed to misunderstandings of the honors program's purposes and values.

\section{Faith-based Academics}

A stated university objective of the honors program (investigated in this study) is to develop students who can "think Christianly." As a result, the development of the students' Christian faith was apparently a primary focus within the program. Interviews 


\section{HONORS PROGRAM AT A FAITH-BASED UNIVERSITY}

with the students reflected this objective in that their respective responses frequently addressed the spiritual dimension of their lives. At this university, however, the integration of a biblically informed faith with rigorous academics is evidently a top priority. Kylie summarized the general opinion in her statement:

I believe [the university], especially the honors program, does an excellent job at the integration concept because it's emphasized, sometimes overly, but emphasized to a point where you can't just say my faith is separate from my work, or my faith is separate from my daily life.

The participants remarked that such an academic approach to their Christian faith resonated with their own personal dispositions. They communicated that they had always been prone to questioning and investigating life issues prior to attending college and they were generally unsatisfied by simplistic or "Sunday school" answers to theological and philosophical questions. For example, Patrick stated: 'I'm a very cerebral person. I enjoy thinking and talking about 'deeper' things." In addition, Drew remarked: "I think that's something...I just grew up asking."

The students therefore considered the honors program to be beneficial in developing them as Christians who were humble and charitable in their views, but also confident and articulate in maintaining them. They related how their experiences in the program expanded their conceptions of God and the Christian faith, altered how they defined their priorities, and changed how they interacted with other people, especially people with whom they did not agree. Michaela summarized the groups' perspectives when she said: 


\section{HONORS PROGRAM AT A FAITH-BASED UNIVERSITY}

Understanding your personal presuppositions allows you to better understand your belief system and your reactions to other belief systems. Furthermore, you cannot rightly critique your own beliefs without first understanding why you hold them or what undergirds them nor can you see the world from another belief system without first understanding their presuppositions.

Several of the participants explained how wrestling with unanswerable questions about theology helped them to more clearly see God as infinite in contrast to human finiteness. Jackson also articulated the participants' development of more ecumenical views when stating: "I think it's really benefitted me in helping me to understand that, first of all, the body of Christ in God's kingdom is a lot broader than just the circles that I grew up in."

As with many of the other themes presented in this study, the participants in the study reported that a primary element of influence in this context was the honors professors. When discussing genuine integration, Neil summarized the student's perspectives:

I think the closest they can get to it is by hiring people who do live a life that reflects Christ. Dr. Edwards...he's great. I love the guy...awesome man. Dr. Martin...great man. Dr. Morris, great guy, I believe he's looking to center his life around God. I can say why these profs that I mentioned do live according to Gospel teaching. They care about their students. They pour into their communities. They do their work with integrity.

As indicated by Neil, the students described these professors as having possessed pathos about their respective academic subjects and their own faith. They were evidently 


\section{HONORS PROGRAM AT A FAITH-BASED UNIVERSITY}

impressed by the excellent academic knowledge and simultaneous religious fervor present in these instructors. Heather's comments illustrated this perception:

One way this whole honors program has been helpful to me is by providing models of people who are Christians who also think very philosophically and critically and are willing to question things if that makes sense. So, it's just nice to have people like that to look up to and to be able to talk to. I think in that way it kind of gives hope to a lot of people, including me, it gives hope that you can think through these things and even come to unconventional conclusions sometimes and maintain a thriving faith.

As a result of the influence of these professors, the participants believed that the honors program provided a more secure environment to engage in theological and philosophical exploration and self-authorship. This belief was best articulated in Alexis' statement: "It's better to have our beliefs challenged in a protected environment rather than to be protected throughout college and have no idea how to handle being challenged in the real world."

Nearly all the honors students, however, acknowledged that self-authorship possessed inherent risks. Several of the students articulated concerns that the program's emphasis on freedom and reaching one's own conclusions potentially hindered the acceptance of adequate conclusions based on Scripture. Esther summarized these concerns when she remarked:

And I think some students become really frustrated with that, because they feel like their foundations are being broken down and not necessarily replaced as quickly as they might like. And the idea is that it will be replaced with the rest of 
HONORS PROGRAM AT A FAITH-BASED UNIVERSITY

the honors program, and I'm not sure, not having taken the seminars, but with fair idea of what the seminars are like, I'm not sure there's enough of a follow-up on MoMM in terms of starting to build up the framework... after giving us a framework with which to work in terms of the chronological arena, not necessarily giving us the tools with which to really start forming a solid foundation.

When addressing these concerns, though, the students seemed hesitant to attribute these potential outcomes directly to the honors program. Most participants emphasized that their own individual outcomes were positive, and considered the primary responsibility to reside with each respective honors member. For instance, Michaela concluded: "Ultimately it requires a student who seeks to understand. The honors program can only go so far, then learning is up to the student." Furthermore, Daryl expressed a common perspective among the students:

I feel like the honors experience assumes that you already have a strong foundation from your Bible minor classes, and wants to expose you to more outside views that you can critique from your Biblical foundation. I don't think there is anything wrong with challenging these concepts, as long as the students have a strong Biblical foundation and it is done in a fair manner. So, while I do think that it is done in a fair manner, I don't think that a lot of the students have a strong Biblical foundation, and I do believe that this has caused problems. In summary, most participants interviewed expressed genuine appreciation for their experiences in the honors program that challenged them toward self-authorship and the broader Christian community. However, they also reported a desire to see more 
HONORS PROGRAM AT A FAITH-BASED UNIVERSITY

direction provided by the instructors. They evidently valued the knowledgeable and experienced perspectives of the professors and desired to take more advantage of their guidance in this development process.

\section{Summary}

The honors students interviewed generally stated that the honors program had an overwhelmingly positive influence on their development as scholars, as believers, and generally as human beings. They felt it prepared them academically for their future endeavors, helped them cultivate a more defined and comprehensive identity, and trained them how to respectfully engage a plurality of ideas and opinions without forfeiting their own. For these students, the honors program represented a juxtaposition of intellectual disturbance and yet communal security. Every student who participated in this study affirmed that they would still complete this honors program, if they could go back in time and again be offered the choice. At the same time, they wrestled with the tensions and potential risks resulting from the open-ended self-authorship encouraged. 
HONORS PROGRAM AT A FAITH-BASED UNIVERSITY

\section{Chapter 5: Discussion}

The purpose of this study was to examine the influence of an honors program at a faith-based university through the perceptions of students who had completed the program. A comprehensive review of literature indicated that colleges and universities continue to use honors program as a principal means of recruiting and serving highachieving students. This trend also occurs in faith-based institutions, which strive to accomplish religious objectives in conjunction with their educational mission. The juxtaposition between the typical goals of honors programs to explore and analyze and the religious goals that often focus on maintaining certain traditions or belief provided the impetus for the study.

\section{Implications and Potential Applications}

The participants in this study highlighted the integrated nature of the honors curriculum as being one of the most influential elements of their program experiences. They perceived that this approach more effectively prepared them for their future endeavors regardless of their chosen field of study by demonstrating the connections and influences of multiple disciplines. Through the historical, philosophical, and theological frameworks developed in the honors program, students indicated that they better understood and appreciated subjects that they previously had not considered enjoyable or relevant. Considering this noted change in perception, even among students in professional disciplines, administrators at the university might consider evaluating how such an approach might be implemented in the regular general education curriculum.

Other components of the honors program elicited less enthusiastic perspectives from the students. The participants mentioned that they felt that freshman sequence, 


\section{HONORS PROGRAM AT A FAITH-BASED UNIVERSITY}

Making of the Modern Mind (MoMM) demonstrated the greatest strengths of the program and that the later elements, comprised mostly of electives, seemed less connected to this strong beginning. Comments from both students and professors indicated that the program intentionally weighted the freshman experience more heavily in order to allow for more focus on studies within the students' respective majors. However, the participants did not feel that the seminars and colloquia adequately articulated their purposes or relationship to the rest of the program. The students particularly desired to see the program follow-up on themes raised earlier, during the freshman sequence. As a result, the program administrators may consider reviewing the objectives of these elements and appraise how they might connect them more concretely to all the other pieces of the program, especially those areas that most profoundly affect student cognitive and spiritual development. Students also indicated a desire to better integrate the honors program into the broader university community. They felt that misconceptions of the program and honors students primarily resulted from lack of knowledge about the program's purposes.

Finally, the participants indicated that their experiences in the honors program prompted significant questioning and analysis of their theological and philosophical belief systems. However, they also noted that the community constructed within the honors program provided a balanced and profitable approach to such analysis. The students felt that they could honestly explore and challenge ideas because of the spirit of freedom and camaraderie. However, they also felt that the tone and foundation of the discussion remained grounded in the essential tenets of the Christian faith, and so did not pressure them to reject these beliefs. On the contrary, most felt that they confirmed and 


\section{HONORS PROGRAM AT A FAITH-BASED UNIVERSITY}

strengthened their religious and philosophical belief systems, and yet were more humble in engaging with discrepant or even oppositional systems. These objectives are stated goals of both this honors program and its host university. The results of this study provide some evidence of success in accomplishing these objectives and that the university as a whole may benefit from expanding the use of techniques utilized within the honors program.

On the other hand, the students also indicated that this questioning and analyzing was particularly unsettling, and may have resulted in negative outcomes for some students. Comments from the program director, other instructors, and course syllabi indicated an intentional focus on mitigating these risks. They encouraged participants in the program to actively seek help and guidance from multiple sources both inside and outside the university context. However, both professors and students emphasized that ultimately the responsibility resides with individual students. According to interviews and reviewed documents, acceptance relies primarily on academic credentials and performance. In contrast, the program evidently requires particular motivations and spiritual backgrounds among its students in order to achieve success. Considering this tension, the university and honors council may want to evaluate the program application and acceptance process to more effectively identify students who may better fit the program goals.

\section{Relation to Other Literature}

Research on collegiate honors programs has been increased in recent years, but continues to be limited compared to elementary and secondary research (Dai et al., 2011). Available data addressing honors students is particularly lacking in regards to participants 


\section{HONORS PROGRAM AT A FAITH-BASED UNIVERSITY}

at religious universities, as noted by Holberg (2010, p. 97), who stated: "Christian colleges have entered the conversation around honors comparatively late." The purpose of the present study was to begin to fill this knowledge gap. Therefore, comparing how the perceptions expressed by the participants in this study with those of other honors students provides valuable insights for effectively serving gifted college students, especially within particular faith traditions. The emergent themes in this study of honors students at a faith-based university were consistent with several areas of research regarding collegiate honors programs. Specifically, this research study supported the conclusions that an integrated liberal arts curriculum, intentional self-authorship, a hospitable learning community, and dedicated and qualified instructors characterized valuable experiences for gifted college students.

In regards to liberal learning outcomes, Seifert, et al. (2008) concluded that liberal arts experiences increased students' inclination for lifelong learning, openness to diversity and challenge, sense of personal growth, and leadership skills. The participants in this study described their experiences in similar terms. The majority indicated an intention to pursue additional education beyond their bachelor degree, and perceived the honors program as having provided learning experiences that were applicable to multiple areas of life. They also noted an apparent connection between participation in honors and serving in leadership roles. Additionally, all the students articulated examples of how their experiences broadened their views regarding theological and philosophical topics and several of them self-reported being more charitable in their responses to alternative opinions. 
HONORS PROGRAM AT A FAITH-BASED UNIVERSITY

In addition to a liberal arts focus, self-authorship was a primary objective of this honors program, as demonstrated in both student and faculty interviews and governing documents. Similar to the observations by Mosier (2012), the honors members in this study decreased their reliance on external authorities for their personal worldviews. Furthermore, they frequently reported researching and discussing topics individually, utilizing a variety of relational and academic resources. This independent development coincided with the examples of "trusting the inner voice" and taking responsibility for one's "reaction to reality" that Mosier highlighted.

Neither the students in this study, nor those of Mosier (2012), progressed toward the elements of self-authorship in isolation but, rather, through participation in community. In contrast to Mosier's research, the honors program at this university developed within a particular course, namely the MoMM freshman sequence. Ladenheim, Kuhns, and Brockington (2011) provided a similar comparison. Their descriptions of the class culture matched those of participants in the honors community investigated here. The shared characteristics included non-judgmental attitudes, freedom to explore ideas, mutual respect, and an emphasis on critical thinking. Hébert and McBee (2007) also noted the emphasis on community in their research. Participants in their study remarked that the honors program connected them with other individuals who shared their interests, passions, and identities that had isolated them in other contexts. In a similar fashion, the students at this university described the honors program as a place where they could find "like-minded" peers that shared their desire for depth and breadth intellectually. 
HONORS PROGRAM AT A FAITH-BASED UNIVERSITY

As reported by the participants, however, the community was not limited to peer interactions. Hébert and McBee (2007) and Ladenheim et al. (2011) both emphasized the role of the professors in the outcomes demonstrated by the participants. Like the students represented in the present study, they described the professors as individuals who dedicated themselves to the students' learning, developed trusting, open relationships with the students, and integrated their personal experiences with the course curricula.

While demonstrating how the present research reflects similar conclusions in the literature, it is also valuable to note instances where these results deviate. As a seminal study regarding honors students' affective development and one of the few to address the perspectives of program alumni, research by Hébert and McBee (2007) provides an important comparison. The themes outlined by Hébert and McBee are consistent at several points to those of the students at this university. However, the three themes of isolation, questioning religious value systems, and search for vocation were either not addressed by the participants in this present study, or did not share the same degree of significance.

First, none of the students articulated feelings of isolation during their college experience or prior to it. In fact, most of them described close relationships with peers, family members, and/or church members. Second, while questioning and analyzing religious value systems was intentionally emphasized, the senior honors students did not see this dynamic as having been incompatible with their religious faith but, more often, an essential exercise to strengthening it. The descriptions included by Hébert and McBee (2007), however, indicated more antagonistic and possibly hostile perspectives toward religious faith. Finally, Hébert and McBee stated: "As they explored various fields of 
HONORS PROGRAM AT A FAITH-BASED UNIVERSITY

study...they shifted their professional goals and made significant changes in their degree programs" (p. 147). In contrast, most participants in the present study reported that the honors program had very little influence on their future plans. Considering that the research completed by Hébert and McBee investigated an honors program at a public technical university, while the present thesis explored experiences at a private, comprehensive, faith-based university, these variations are worthy of further examination.

As noted in the previous literature comparisons, the campus context may have influenced the differences between research results. For instance, research by Kneipp et al. (2011) reported that students who attended private religious institutions were more intrinsically religious, and that they were reinforced in their beliefs by attending this type of college. This may explain why honors members at the present university maintained a more favorable view toward integrating faith and intellectual pursuits. On the other hand, Mayhew and Bryant (2013) determined that a coercive environment, described as pressuring individuals to participate in specific religious activities or conform to particular ideological perspectives, hindered the commitment of those individuals to any worldview, especially one that was self-authored. In the current study, the honors students generally described the honors program as open, in contrast to coercive. Similar to the observations by Mayhew and Bryant regarding the influence of campus context, participants in the present honors program characterized their experiences as consistent with self-authorship and frequently articulated strong commitments to their respective worldviews. 
HONORS PROGRAM AT A FAITH-BASED UNIVERSITY

\section{Biblical Integration Component and Implications}

This research thesis investigated the experiences of gifted college students participating in an honors program at a faith-based institution. Therefore, it is also valuable to explore a biblical perspective on education as it occurs within the honors context. This discussion is not exhaustive, but highlights some basic principles addressing these areas of research.

From the beginning, the Bible describes human beings as a unique creation, set apart from all other created beings (Genesis 1). Humans were the only creatures created in God's own image, into which it is said that God breathed the "breath of life," the only ones given dominion over the entirety of the earth (Genesis 2). Furthermore, the first command given by God to humans was to "Be fruitful and increase in number; fill the earth and subdue it" (Genesis 1:28a). Inherent in this first command was the development of culture and education in its most basic forms. Without exploring the creation, including humanity itself, and learning about it, Adam and Eve could not have fulfilled this command. The creation narrative, however, also implied that human learning and dominion included submission to the Creator. The rejection of this submission, and the initial attempt by humans to define truth apart from God, resulted in the fragmented and decaying existence we experience today (Genesis 3). Since that time, all education is fundamentally humanity's attempts to either continue to fulfill our first command or to bring about some degree of reconciliation within the broken existence of the creation.

Based on these assumptions, Christian universities perform a distinctive function within higher education. In Romans 1:21, the Apostle Paul declared that those who reject God experience a life of futility, unable and unwilling to accept ultimate truth. He also 


\section{HONORS PROGRAM AT A FAITH-BASED UNIVERSITY}

states in 1 Corinthians 2: 6-14 that those who receive Christ's free gift of salvation by faith also receive the Holy Spirit of God, who allows them to comprehend truth.

Furthermore, those who claim to be followers of Christ were given an additional command to preach the good news of salvation to the world, make disciples, and teach them to obey God's commands (Matthew 28:19-20; Mark 16:15-16). This command forms the foundational purpose of Christian education. Christian universities often add to this command the principles of reconciliation and stewardship. In 2 Corinthians 5:18-20, Paul explains that God is reconciling the world to Himself through Christ, and that His followers are ambassadors and ministers of this reconciliation. The principle of stewardship is built on the statements in 1 Peter 4:10-11, when Peter exhorts the Christians to use whatever gifts they have for the service of others. These principles provide a purpose for engaging a sinful, broken, and depraved world. By growing in knowledge and wisdom, both spiritually and academically, followers of Christ can use their gifts to glorify God and effectively communicate the message of reconciliation to the world.

In regards to making disciples, the Bible also provides several principles for Christian universities about teaching and training other Christians. Romans 12:1-2 emphasizes that an essential part of life worship to God includes the renewing of one's mind. Second, Ephesians 4:11-16 explains that God's Spirit imparts various leadership and teaching gifts to some so that every individual in the church can attain spiritual maturity and not be led away from the truth by finite or sinful human reasoning. Finally, the Apostle Paul challenges Christians in 1 Thessalonians 5:21-22 to "Test everything. Hold on to the good. Avoid every kind of evil." These verses imply that, while living in 


\section{HONORS PROGRAM AT A FAITH-BASED UNIVERSITY}

the Spirit can lead to truth, and Christians are to pursue such knowledge, believers also must carefully evaluate knowledge and wisdom to sift out what is truly God's truth and what comes from the sinfulness that can cause Christians to stumble.

Considering that these principles are generally expressed in universal terms for all Christians, the objectives of honors programs, which focus on enhancing the educational experiences of only select individuals, may initially appear to be incongruent. However, the parable of the talents in Matthew 25:14-30 provides a more holistic perspective toward the matter. In this account, the amount entrusted was not relevant, but the stewards were instead judged on their faithfulness in developing and multiplying the talent. In response, Christian educators have a responsibility to develop all of their students in accordance with their abilities, from those who may struggle with the most simplistic educational tasks, to the extremely bright who have significant intellectual potential for influencing many for the cause of Christ.

Finally, 2 Timothy 1:13-14 and 2:2, 1 Corinthians 3:10-15, and James 3:1 articulate some responsibilities that all Christian educators should take seriously, but especially those who instruct collegiate honors students. In 2 Timothy, the Apostle Paul wrote:

What you heard from me, keep as the pattern of sound teaching, with faith and love in Christ Jesus. Guard the good deposit that was entrusted to you-guard it with the help of the Holy Spirit who lives in us. And the things you have heard me say in the presence of many witnesses entrust to reliable people who will also be qualified to teach others. [Emphasis added] 


\section{HONORS PROGRAM AT A FAITH-BASED UNIVERSITY}

This passage indicates that both methods and student character are important as

professors look to develop Christians who have the potential to lead others. Additionally, 1 Corinthians 3 proposes that the process of teaching will be judged as much as the outcomes when it warns leaders "each one should be careful how he builds" (v. 10b). Furthermore, James 3:1 indicates that teachers will ultimately face a stricter evaluation because of their leadership position.

\section{Strengths of the Study}

I designed this study to access thick, rich descriptions of the experiences of honors students in a collegiate honors program. In order to accomplish this purpose, I conducted interviews with participants who met a set of pre-determined criteria. These conditions provided access to students who had not only nearly completed their postsecondary education, including the honors program, but were still present in the context being investigated. As a result, the experiences upon which the participants reflected were still fresh, and the information provided was relevant to the current program and its students. Furthermore, I obtained perspectives from two separate cohorts who completed the program at different times, but within two years. Both cohorts met the same criterion for interviews, but the variation strengthens the generalization of results to other honors students at this comprehensive, Midwestern university and others like it.

Consistency in the sample and interview process enhanced the internal validity of this study. All 25 participants attended the same university, and completed the same honors program requirements. I also used the same semi-structured interview guides for each wave of student interviews. The second wave of interviews more directly addressed highlighted themes, but did not provide any novel or contradictory information. A more 
HONORS PROGRAM AT A FAITH-BASED UNIVERSITY

thorough understanding of the honors program context was obtained through triangulation. Observations of the students participating in some honors experiences, interviews with the administrator and professors in the program, and review of program documents strengthen the connection of the participants' reflections to actual elements of the program.

In order to ensure that the findings were grounded in the actual statements of the honors students, I used low-inference descriptors when articulating the results. I purposefully included broad and deep verbatim responses from participants that best represented the sample as a whole. Furthermore, all students were asked to review and verify their respective transcripts. I also utilized member checks by requesting a select sample of the participants to review the results and indicate their general agreement with the themes.

\section{Limitations of the study}

Remaining threats to internal validity. Although, the interviews provided a rich and consistent data set, the possibility remains that students were reluctant to portray the honors program in a negative light. The prevalence of favorable perspectives might also have resulted from an element of selective memory or bias, which can occur over any length of time between an experience and one's reflection on it. These students had elected to complete all the requirements of a challenging academic program. This decision to persist usually coincided with positive experiences in the program. Those students who did not persist in the program might have provided alternative perspectives regarding the program. 
HONORS PROGRAM AT A FAITH-BASED UNIVERSITY

Remaining threats to external validity. I did not use a random sample for this study, which means that results potentially may not be generalized to honors programs at other universities. In contrast, the research objectives were best accomplished through purposeful, criterion sampling. This method precluded randomization and limited the sample to senior honors students at a particular Midwestern university. The participants all attended a single university, which has a population of about 3,400 students. All the students interviewed were Caucasian, and minority students comprised only $8 \%$ of the undergraduate enrollment. The distribution of male and female participants ( $48 \%$ and $52 \%$ respectively) closely resembled the university they attended. However, I could not locate any national statistics on honors program participation by which to compare this sample. The results of this study may be restricted from generalization to other collegiate honors programs by the limited sampling and generally homogenous participant group. However, it is possible that the themes presented in this study may be indicative of honors programs at similar, faith-based universities.

\section{Suggestions for future research}

For the honors students in this study, positive experiences in the program influenced their completion of the program. Several students indicated that they had considered quitting because of conflicting responsibilities and difficult class scheduling. They also described the later elements, seminars and colloquia, as more disorganized and having less clear objectives, despite still perceiving them as "interesting" and “enjoyable.” Robbins (2010) reported that non-completers in that honors program expressed more negative perceptions of the program. They also described their program as disorganized and not having good communication regarding objectives, benefits, and 


\section{HONORS PROGRAM AT A FAITH-BASED UNIVERSITY}

requirements. These similar descriptions indicate that the experiences of students who begin but do not complete an honors program need to be investigated further.

Comparisons of completers and non-completers may provide suggestions for program improvements or identify personal characteristics in applicants that might help program better select participants who are more likely to succeed.

The honors program investigated in this study also followed a purposefully integrated curriculum that connected multiple academic disciplines. The students also reported wrestling with significant questions regarding their religious beliefs and personal identities. Arnett (2011) described this period of exploration and identity formation as emerging adulthood. Furthermore, Labouvie-Vief (2006) indicated that more advanced cognitive growth correlates with the level of educational attainment. This connection warrants further investigation, particularly regarding participation in an honors program. The students interviewed in the current study described their modes of thinking and values as more mature than their peers, and made interaction with these peers more difficult. Addition research would be valuable to investigate whether or not participation in an honors program significantly affects cognitive and identity development through the stage of emerging adulthood.

Finally, while the students in this study and other research (Mosier, 2012; Zieniuk, 2012) believe that they have been well prepared for their post-graduate experiences, very little research is available that explores whether these perceptions were accurate. Hébert and McBee (2007) and Perrone et al. (2010) are the only two studies available that had investigated the perceptions of collegiate honors students after they had graduated. However, only Hébert and McBee specifically addressed their participants' 


\section{HONORS PROGRAM AT A FAITH-BASED UNIVERSITY}

post-graduate experiences as it related to their honors program. Research in this area would benefit honors programs by connecting students' perceptions with actual outcomes. The results of such research would not only allow honors administrators to better assess their specific programs, but may identify valuable learning experiences for all college students. 
HONORS PROGRAM AT A FAITH-BASED UNIVERSITY

\section{References}

Altbach, P. G., Gumport, P. J., \& Berdahl, R. O. (2011). American higher education in the twenty-first century: Social, political, and economic challenges. Baltimore, MD: Johns Hopkins University Press.

American Association of Colleges and Universities (AAC\&U). (2002). Greater expectations: A new vision for learning as a nation goes to college. Washington: AAC\&U.

Anderson, L. W. (2003). Benjamin S. Bloom: His life, his works, and his legacy. In B. J. Zimmerman, \& D. H. Schunk (Eds.), Educational psychology: A century of contributions (pp. 367-390). Mahwah, NJ: Lawrence Erlbaum Associates.

Andrews, L. (2011). The wisdom of our elders: Honors discussions in the superior student, 1958-65. Journal of the National Collegiate Honors Council, 12, 17-46.

Arnett, J. J. (2011). Emerging adulthood(s): The cultural psychology of a new life stage. In L. A. Jensen (Ed.), Bridging cultural and developmental approaches to psychology (pp. 255-275). New York, NY: Oxford University Press.

Arthur, J. (2006). Faith and secularisation in religious colleges and universities. London, UK: Routledge.

Badenhausen, R. (2012). Costs and benefits in the economy of honors. Journal of the National Collegiate Honors Council, 13, 15-22.

Barry, C., \& Nelson, L. (2005). The role of religion in the transition to adulthood for young emerging adults. Journal of Youth \& Adolescence, 34, 245-255. 
HONORS PROGRAM AT A FAITH-BASED UNIVERSITY

Bartelds, V., Drayer, L., \& Wolfensberger, M. V. C. (2012). Mission, performance indicators, and assessment in U. S. honors: A view from the Netherlands. Journal of the National Collegiate Honors Council, 13, 129-145.

Bloom, B. S., Engelhart, M. D., Furst, E. J., Hill, W. H., \& Krathwohl, D. R. (1956). Taxonomy of educational objectives: Handbook I: Cognitive domain. New York, NY: David McKay.

Boazman, J. K. (2011). Well-being and academic success in gifted college students: Early-college entrants and honors college students. Dissertation Abstracts International Section A: Humanities and Social Sciences, 72(5-A), 1552.

Bratt, K. (2010). Hearts and minds: Honors programs in North American Christian institutions. Journal of Education \& Christian Belief, 14, 7-18.

Bryant, A. (2011). The impact of campus context, college encounters, and religious/spiritual struggle on ecumenical worldview development. Research in Higher Education, 52, 441-459.

Carnicom, S. (2011). Honors education: Innovation or conservation? Journal of the National Collegiate Honors Council, 12, 49-54.

Cedarville University. (2013). Honors program. Retrieved February 13, 2013, from http://www.cedarville.edu/Academics/Honors.aspx

Cedarville University. (2013). Admission criteria. Retrieved February 13, 2013, from https://www.cedarville.edu/Admissions/Admission-Guidelines/Admission-

\section{$\underline{\text { Criteria.aspx }}$}

Chenail, R. J. (2012). Conducting qualitative data analysis: Managing dynamic tensions within. The Qualitative Report, 17, 1-6. 
HONORS PROGRAM AT A FAITH-BASED UNIVERSITY

Clauss, J. J. (2011). The benefits of honors education for all college students. Journal of the National Collegiate Honors Council, 12, 95-100.

Cobane, C. T. (2011). Moving mountains: Honors as leverage for institutional change. Journal of the National Collegiate Honors Council, 12, 101-104.

Corbin, J., \& Strauss, A. (2008). Basics of qualitative research (3rd ed.). Thousand Oaks, CA: Sage.

Cossentino, A. L. (2007). Understanding the experiences, satisfaction and performance of honors students: A multisite case study at public higher education institutions (Doctoral dissertation). Available from ProQuest Dissertations and Theses. (UMI No. 304843004)

Council for Christian Colleges \& Universities. (2010). Member List. Retrieved September 2010 from http://www.cccu.org/about/profile.

Council for Christian Colleges \& Universities. (2013) CCCU profile 2012-2013. Retrieved February 13, 2013, from http://www.cccu.org/about/profile.

Council for Christian Colleges \& Universities. (2013) Member List. Retrieved February 13, 2013, from http://www.cccu.org/about/profile.

Creswell, J. W. (2013). Qualitative inquiry and research design: Choosing among five approaches. Thousand Oaks, CA: Sage.

Dai, D. Y., Swanson, J. A., \& Cheng, H. (2011). State of research on giftedness and gifted education: A survey of empirical studies published during 1998-2010 (April). Gifted Child Quarterly, 55, 126-138. 
HONORS PROGRAM AT A FAITH-BASED UNIVERSITY

DeHart, K. E. (1993). A comparative study of two northeast Ohio universities' honors programs: The University of Akron and Kent State University (Doctoral dissertation). Available from ProQuest Dissertations and Theses. (UMI No. 304029751)

Dooley, K. L. (2011). Defending the traditions by preserving the classics. Journal of the National Collegiate Honors Council, 12, 55-58.

Eby, J. W., \& Smutny, J. F. (1990). A thoughtful overview of gifted education. New York, NY: Longman.

England, R. (2010). Honors programs in four-year institutions in the northeast: A preliminary survey toward a national inventory of honors. Journal of the National Collegiate Honors Council, 11, 71-82.

Fisler, J., Agati, H. A., Chance, S. M., Donahue, A. E., Donahue, G. A., Eickhoff, E. J., Foubert, J. D. (2009). Keeping (or losing) the faith: Reflections on spiritual struggles and their resolution by college seniors. College Student Affairs Journal, $27,257-274$.

Flick, V. (2006). An introduction to qualitative research (3rd. ed.). Thousand Oaks, CA: Sage.

Floyd, D. L., \& Holloway, A. (2006). Prioritizing service to the academically talented: The honors college. New Directions for Community Colleges, 136, 43-52.

Franklin, S. T. (1995). Theological foundations of the Christian liberal arts in relation to the distinctives of the Christian liberal arts college/university. Christian Scholars Review, 24, 253-77. 


\section{HONORS PROGRAM AT A FAITH-BASED UNIVERSITY}

Fraternity. (2013). In New Oxford American dictionary online ( $3^{\text {rd. }}$ ed.). Retrieved February 28, 2013 from http://oxforddictionaries.com/definition/english/fraternity?q=fraternity

Gonyea, R. M., Kuh, G. D., Kinzie, J., Cruce, T., \& Nelson-Laird, T. F. (2010). Expectations and engagement: How liberal arts college students compare with counterparts elsewhere. Retrieved from Center of Inquiry in the Liberal Arts at Wabash College http://www.liberalarts.wabash.edu/storage/Expectations_Engagement_LACs_Gon yea_EtAl.pdf

Haynes, C. (2006). The integrated student: Fostering holistic development to advance learning. About Campus, 10, 17-23.

Hébert, T. P., \& McBee, M. T. (2007). The impact of an undergraduate honors program on gifted university students. Gifted Child Quarterly, 51, 136-151.

Hill, J. P. (2009). Higher education as moral community: Institutional influences on religious participation during college. Journal for the Scientific Study of Religion, $48,515-534$.

Holberg, J. L. (2010). Afterwords. Journal of Education \& Christian Belief, 14, 97-99.

Kem, L., \& Navan, J. L. (2006). Gifted students in college: Suggestions for advisors and faculty members. NACADA Journal, 26, 21-28.

King, N., \& Horrocks, C. (2010). Interviews in qualitative research. Thousand Oaks, CA: Sage.

Kitagaki, I., \& Li, D. (2012). On training excellent students in China and the United States. Journal of the National Collegiate Honors Council, 13, 119-128. 
HONORS PROGRAM AT A FAITH-BASED UNIVERSITY

Kneipp, L. B., Kelly, K. E., \& Dubois, C. (2011). Religious orientation: The role of college environment and classification. College Student Journal, 45, 143-150.

Kronholz, J. (2011). High schoolers in college: Dual enrollment programs offers something for everyone. Education Next, 11, 26-31.

Ksiazak, T. M. (2010). Development of the Ksiazak adult giftedness scale (Doctoral dissertation). Available from ProQuest Dissertations and Theses. (UMI No. $859017159)$

Kuh, G. D., \& Gonyea, R. M. (2006). Spirituality, liberal learning and college student engagement. Liberal Education, 92, 40-47.

Kvale, S., \& Brinkmann, S. (2009). Interviews: Learning the craft of qualitative research. Thousand Oaks, CA: Sage.

Labouvie-Vief, G. (2006). Emerging structures of adult thought. In J. J. Arnett, \& J. L. Tanner (Eds.), Emerging adults in America: Coming of age in the 21st century (pp. 59-84). Washington, D.C.: American Psychological Association.

Ladenheim, M., Kuhns, K., \& Brockington, M. (2011). Ethnogenesis: The construction and dynamics of the honors classroom culture. Journal of the National Collegiate Honors Council, 12, 129-140.

Long, B. T. (2002). Attracting the best: The use of honors programs to compete for students. Chicago, IL: Spencer Foundation.

Mayhew, M. J., \& Bryant, A. N. (2013). Achievement or arrest? The influence of the collegiate religious and spiritual climate on students' worldview commitment. Research in Higher Education, 54, 63-84. 


\section{HONORS PROGRAM AT A FAITH-BASED UNIVERSITY}

McClain, M., \& Pfeiffer, S. (2012). Identification of gifted students in the United States today: A look at state definitions, policies, and practices. Journal of Applied School Psychology, 28, 59-88.

Mero-Jaffe, I. (2011). 'Is that what I said?' interview transcript approval by participants: An aspect of ethics in qualitative research. International Journal of Qualitative Methods, 10, 231-247.

Merriam, S. B. (2009). Qualitative research: A guide to design implementation. San Francisco, CA: John Wiley \& Sons.

Miles, M. B., \& Huberman, A. M. (1994). Qualitative data analysis: An expanded sourcebook (2nd ed.). Thousand Oaks, CA: Sage.

Mitchell, P. (2010). I want some freedom for my people: Baptists, great texts, and honors education. Journal of Education \& Christian Belief, 14, 47-67.

Mosier, S. K. (2012). Creating experiences that matter: A qualitative study exploring honors program peer mentoring and self-authorship development (Master's thesis, University of Nebraska - Lincoln). Retrieved from http://digitalcommons.unl.edu/cehsedaddiss/93/

Mulcahy, D. G. (2009). What should it mean to have a liberal education in the $21^{\text {st }}$ Century? Curriculum Inquiry, 39, 465-486.

National Collegiate Honors Council. (2013) Join. Retrieved February 13, 2013, from http://nchchonors.org/join/ 


\section{HONORS PROGRAM AT A FAITH-BASED UNIVERSITY}

National Collegiate Honors Council. (2010). National collegiate honors council constitution \& bylaws. Retrieved February 13, 2013, from http://nchchonors.org/wp-content/uploads/2012/02/Constitution-Bylaws$\underline{\text { Standing-Orders.pdf }}$

New, K. H., \& Ghafar, M. N. A. (2012). The role of education in transforming the potential social skills of college students. Excellence in Higher Education, 3, 95103.

No Child Left Behind Act of 2001, 20 U.S.C. $§ 7801$ et seq. (2002).

Noll, M. A. (2006). Introduction. In W. C. Ringenberg (Ed.), The Christian college: A history of protestant higher education in America (2nd ed., pp. 1-36). Grand Rapids, MI: Baker Academic.

Otero, R., \& Spurrier, R. (2005). Assessing \& evaluating honors programs \& honors colleges: A practical handbook. Lincoln, NE: National Collegiate Honors Council.

Patton, M. Q. (2002). Qualitative research and evaluation methods (3rd ed.). Thousand Oaks, CA: Sage.

Perrone, K. M., Wright, S. L., Ksiazak, T. M., Crane, A. L., \& Vannatter, A. (2010). Looking back on lessons learned: Gifted adults reflect on their experiences in advanced classes. Roeper Review, 32, 127-139.

Peruso, D. F. (2011). Fit, fat, or failing? The financial health of private higher education. Juniata Voices, 11, 54-73.

Peterson's Christian colleges \& universities. (2002). Princeton, NJ: Peterson's. 


\section{HONORS PROGRAM AT A FAITH-BASED UNIVERSITY}

Pfeiffer, S. I. (2012). Current perspectives on the identification and assessment of gifted students. Journal of Psychoeducational Assessment, 30, 3-9.

Prudent. (2013) In Merriam-Webster's online dictionary. Retrieved February 28, 2013 from http://www.merriam-webster.com/dictionary/prudent

Ringenberg, W. C. (2006). The Christian college: A history of protestant higher education in America (2nd ed.). Grand Rapids, MI: Baker Academic.

Robbins, G. A. (2010). To participate or not to participate: The perceptions of gifted students regarding an honors program at a private southeastern university (Doctoral dissertation, Mercer University). Available from ProQuest Dissertations and Theses. (UMI No. 746606142)

Rodgers, B. (2008). Audit trail. In L. Given (Ed.), The Sage encyclopedia of qualitative research methods (pp. 43-44). Thousand Oak, CA: Sage.

Rubin, I. S., \& Rubin, H. J. (2011). Qualitative interviewing: The art of hearing data. Thousand Oaks, CA: Sage.

Schroeder, D. S., Bruce, M., \& Bogue, S. E. (2011). The roles and activities of honors directors: Similarities and differences across Carnegie institution types. Journal of the National Collegiate Honors Council, 12, 107-144.

Seidman, I. (2006). Interviewing as qualitative research: A guide for researchers in education and the social sciences (3rd ed.). New York, NY: Teachers College Press.

Seifert, T. A., Goodman, K. A., Lindsay, N., Jorgensen, J. D., Wolniak, G. C., Pascarella, E. T., \& Blaich, C. (2008). The effects of liberal arts experiences on liberal arts outcomes. Research in Higher Education, 49, 107-125. 
HONORS PROGRAM AT A FAITH-BASED UNIVERSITY

Seifert, T. A., Pascarella, E. T., Colangelo, N., \& Assouline, S. (2007). The effects of honors program participation on experiences of good practices and learning outcomes. Journal of College Student Development, 48, 57-74.

Siegle, D. (2011). The changing nature of universities: Going online. Gifted Child Today, $34,56-61$.

Sin, S. (2010). Considerations of quality in phenomenographic research. International Journal of Phenomenographic Research, 9, 305-319.

Slavin, C., Coladarci, T., \& Pratt, P. A. (2008). Is student participation in an honors program related to retention and graduation rates? Journal of the National Collegiate Honors Council, 9, 59-69.

Snyder, C. A., \& Carnicom, S. (2011). Assessment, accountability, and honors education. Journal of the National Collegiate Honors Council, 12, 111-127.

Storrs, D., \& Clott, L. (2008). A qualitative study of honor students' learning orientations: The rare liberal scholar. College Student Journal, 42, 57-69.

Tannenbaum, A. J. (2002). A history of giftedness in school and society. In K. A. Heller, F. J. Monks, R. Subotnik \& R. J. Sternberg (Eds.), International handbook of giftedness and talent (2nd. ed., pp. 23). Amsterdam, NL: Elsevier.

Tracy, S. J. (2010). Qualitative quality: Eight 'big tent' criteria for excellent qualitative research. Qualitative Inquiry, 16, 837-851.

Tudge, J. \& Scrimsher S. (2003). Lev D. Vygotsky on education: A cultural-historical, interpersonal, and individual approach to development. In B. J. Zimmerman, \& D. H. Schunk (Eds.), Educational psychology: A century of contributions (pp. 207228). Mahwah, NJ: Lawrence Erlbaum Associates. 


\section{HONORS PROGRAM AT A FAITH-BASED UNIVERSITY}

Vygotsky, L. S., \& Kozulin, A. (1986). Thought and language. Cambridge, MA: MIT Press.

Wawrzynski, M. R., Madden, K., \& Jensen, C. (2012). The influence of the college environment on honors students' outcomes. Journal of College Student Development, 53, 840-845.

Wilson, H. E., \& Adelson, J. L. (2012). College choices of academically talented secondary students. Journal of Advanced Academics, 23, 32-52.

Zieniuk, V. (2012). The impact on selected students participating in the Thomas $N$. Bantivoglio honors concentration at Rowan University (Master's thesis, Rowan University). Retrieved from http://dspace.rowan.edu/handle/10927/255 
Appendix A

\section{Honors Offerings at CCCU Colleges \& Universities}

\begin{tabular}{|c|c|c|c|c|c|c|c|}
\hline Institution & $\begin{array}{l}\text { CCCU } \\
\text { Status }\end{array}$ & $\begin{array}{l}\text { Honors } \\
\text { Program }\end{array}$ & $\begin{array}{l}\text { Honors } \\
\text { College }\end{array}$ & $\begin{array}{l}\text { Honors } \\
\text { Courses }\end{array}$ & General & $\begin{array}{l}\text { Field- } \\
\text { specific }\end{array}$ & $\begin{array}{l}\text { NCHC } \\
\text { Member }\end{array}$ \\
\hline Abilene Christian University & $\mathrm{M}$ & & $\mathrm{X}$ & $\mathrm{X}$ & $\mathrm{X}$ & $\mathrm{X}$ & $\mathrm{X}$ \\
\hline Anderson University & $\mathrm{M}$ & $\mathrm{X}$ & & $\mathrm{X}$ & $\mathrm{X}$ & & $\mathrm{X}$ \\
\hline Anderson University & $\mathrm{M}$ & $\mathrm{X}$ & & $\mathrm{X}$ & $\mathrm{X}$ & & \\
\hline Asbury university & $\mathrm{M}$ & $\mathrm{X}$ & $\mathrm{X}$ & & & & \\
\hline Azusa Pacific University & $\mathrm{M}$ & $\mathrm{X}$ & & $\mathrm{X}$ & $\mathrm{X}$ & $\mathrm{X}$ & $\mathrm{X}$ \\
\hline Baylor University & A & $\mathrm{X}$ & $\mathrm{X}$ & $\mathrm{X}$ & $\mathrm{X}$ & & $\mathrm{X}$ \\
\hline Belhaven University & $\mathrm{M}$ & & $\mathrm{X}$ & $\mathrm{X}$ & $\mathrm{X}$ & $\mathrm{X}$ & \\
\hline Bethel College & $\mathrm{M}$ & & & & & & \\
\hline Bethel university & $\mathrm{M}$ & $\mathrm{X}$ & & $\mathrm{X}$ & $\mathrm{X}$ & & \\
\hline Biola university & $\mathrm{M}$ & $\mathrm{X}$ & & $\mathrm{X}$ & $\mathrm{X}$ & & \\
\hline Bluefield College & $\mathrm{M}$ & $\mathrm{X}$ & & $\mathrm{X}$ & $\mathrm{X}$ & $\mathrm{X}$ & \\
\hline Bluffton University & $\mathrm{M}$ & $\mathrm{X}$ & & $\mathrm{X}$ & $\mathrm{X}$ & & $\mathrm{X}$ \\
\hline Bryan College & $\mathrm{M}$ & $\mathrm{X}$ & & $\mathrm{X}$ & $\mathrm{X}$ & & $\mathrm{X}$ \\
\hline California Baptist University & $\mathrm{M}$ & $\mathrm{X}$ & & $\mathrm{X}$ & $\mathrm{X}$ & & \\
\hline Calvin College & $\mathrm{M}$ & $\mathrm{X}$ & & $\mathrm{X}$ & & $\mathrm{X}$ & $\mathrm{X}$ \\
\hline Campbell University & A & $\mathrm{X}$ & & $\mathrm{X}$ & $\mathrm{X}$ & & \\
\hline Campbellsville University & $\mathrm{M}$ & $\mathrm{X}$ & & $\mathrm{X}$ & $\mathrm{X}$ & & \\
\hline Carson-Newman University & $\mathrm{M}$ & $\mathrm{X}$ & & $\mathrm{X}$ & $\mathrm{X}$ & $\mathrm{X}$ & $\mathrm{X}$ \\
\hline Cedarville University & $\mathrm{M}$ & $\mathrm{X}$ & & $\mathrm{X}$ & $\mathrm{X}$ & & \\
\hline Charleston Southern University & $\mathrm{M}$ & $\mathrm{X}$ & & $\mathrm{X}$ & $\mathrm{X}$ & & \\
\hline College of the Ozarks & $\mathrm{M}$ & & & & & & \\
\hline Colorado Christian University & $\mathrm{M}$ & & & & & & \\
\hline Concordia University Irvine & $\mathrm{M}$ & $\mathrm{X}$ & & $\mathrm{X}$ & $\mathrm{X}$ & $\mathrm{X}$ & $\mathrm{X}$ \\
\hline Corban University & $\mathrm{M}$ & $X$ & & $\mathrm{X}$ & $\mathrm{X}$ & & \\
\hline Cornerstone university & $\mathrm{M}$ & $\mathrm{X}$ & & & & & \\
\hline Covenant College & $\mathrm{M}$ & & & & & & \\
\hline Crown College & $\mathrm{M}$ & $\mathrm{X}$ & & $\mathrm{X}$ & $\mathrm{X}$ & $\mathrm{X}$ & \\
\hline Dallas Baptist University & $\mathrm{M}$ & $\mathrm{X}$ & & $\mathrm{X}$ & $\mathrm{X}$ & $\mathrm{X}$ & $\mathrm{X}$ \\
\hline Dordt College & $\mathrm{M}$ & $\mathrm{X}$ & & $\mathrm{X}$ & $\mathrm{X}$ & & $\mathrm{X}$ \\
\hline East Texas Baptist University & $\mathrm{M}$ & $\mathrm{X}$ & & $\mathrm{X}$ & $\mathrm{X}$ & & $\mathrm{X}$ \\
\hline Eastern Mennonite University & $\mathrm{M}$ & $\mathrm{X}$ & & $\mathrm{X}$ & & & \\
\hline Eastern Nazarene College & $\mathrm{M}$ & $\mathrm{X}$ & & $\mathrm{X}$ & $\mathrm{X}$ & & $\mathrm{X}$ \\
\hline Eastern University & $\mathrm{M}$ & & $\mathrm{X}$ & $\mathrm{X}$ & $\mathrm{X}$ & & $\mathrm{X}$ \\
\hline Emmanuel College & $\mathrm{M}$ & $\mathrm{X}$ & & $\mathrm{X}$ & $\mathrm{X}$ & & \\
\hline Erskine College & $\mathrm{M}$ & & & & & & \\
\hline Evangel University & $\mathrm{M}$ & & & & & & \\
\hline Fresno Pacific university & $\mathrm{M}$ & & & & & & \\
\hline Geneva College & $\mathrm{M}$ & $\mathrm{X}$ & & $\mathrm{X}$ & $\mathrm{X}$ & & $\mathrm{X}$ \\
\hline George Fox university & $\mathrm{M}$ & $\mathrm{X}$ & & $\mathrm{X}$ & $\mathrm{X}$ & & \\
\hline Gordon College & $\mathrm{M}$ & $\mathrm{X}$ & & $\mathrm{X}$ & $\mathrm{X}$ & $\mathrm{X}$ & \\
\hline Goshen College & $\mathrm{M}$ & $\mathrm{X}$ & & $\mathrm{X}$ & & $\mathrm{X}$ & \\
\hline Grace College \& Seminary & $\mathrm{M}$ & & & & & & \\
\hline Greenville college & $\mathrm{M}$ & $\mathrm{X}$ & & $\mathrm{X}$ & $\mathrm{X}$ & & \\
\hline Hannibal-LaGrange University & $\mathrm{M}$ & $\mathrm{X}$ & & $\mathrm{X}$ & & & \\
\hline Hardin-Simmons University & $\mathrm{M}$ & $\mathrm{X}$ & & $\mathrm{X}$ & $\mathrm{X}$ & & $\mathrm{X}$ \\
\hline Hope International University & $\mathrm{M}$ & & & & & & \\
\hline Houghton College & $\mathrm{M}$ & $\mathrm{X}$ & & $\mathrm{X}$ & $\mathrm{X}$ & $\mathrm{X}$ & \\
\hline
\end{tabular}


HONORS PROGRAM AT A FAITH-BASED UNIVERSITY

\begin{tabular}{|c|c|c|c|c|c|c|c|}
\hline Institution & $\begin{array}{l}\text { CCCU } \\
\text { Status } \\
\end{array}$ & $\begin{array}{l}\text { Honors } \\
\text { Program }\end{array}$ & $\begin{array}{l}\text { Honors } \\
\text { College }\end{array}$ & $\begin{array}{l}\text { Honors } \\
\text { Courses }\end{array}$ & General & $\begin{array}{c}\text { Field- } \\
\text { specific }\end{array}$ & $\begin{array}{l}\text { NCHC } \\
\text { Member }\end{array}$ \\
\hline Houston Baptist University & $\mathrm{M}$ & & $\mathrm{X}$ & $\mathrm{X}$ & $\mathrm{X}$ & & \\
\hline Howard Payne University & $\mathrm{M}$ & $\mathrm{X}$ & & $\mathrm{X}$ & $\mathrm{X}$ & & \\
\hline Huntington University & $\mathrm{M}$ & & & & & & \\
\hline Indiana Wesleyan University & $\mathrm{M}$ & & $\mathrm{X}$ & $\mathrm{X}$ & $\mathrm{X}$ & & $\mathrm{X}$ \\
\hline John Brown University & $\mathrm{M}$ & $\mathrm{X}$ & & $\mathrm{X}$ & $\mathrm{X}$ & & $\mathrm{X}$ \\
\hline Judson College & $\mathrm{M}$ & $\mathrm{X}$ & & & & & \\
\hline Judson University & $\mathrm{M}$ & $\mathrm{X}$ & & $\mathrm{X}$ & $\mathrm{X}$ & & \\
\hline Kentucky Christian University & $\mathrm{M}$ & & & & & & \\
\hline King college & $\mathrm{M}$ & $\mathrm{X}$ & & $\mathrm{X}$ & $\mathrm{X}$ & & \\
\hline King's University College & $\mathrm{M}$ & & & & & & \\
\hline Lee University & $\mathrm{M}$ & $\mathrm{X}$ & & $\mathrm{X}$ & $\mathrm{X}$ & $\mathrm{X}$ & \\
\hline LeTourneau University & $\mathrm{M}$ & & $\mathrm{X}$ & $\mathrm{X}$ & & $\mathrm{X}$ & $\mathrm{X}$ \\
\hline Lipscomb University & $\mathrm{M}$ & & $\mathrm{X}$ & $\mathrm{X}$ & $\mathrm{X}$ & & \\
\hline Louisiana College & $\mathrm{M}$ & & & & & & \\
\hline Malone University & $\mathrm{M}$ & $\mathrm{X}$ & & $\mathrm{X}$ & $\mathrm{X}$ & $\mathrm{X}$ & $\mathrm{X}$ \\
\hline Master's College \& Seminary & $\mathrm{M}$ & & & & & & \\
\hline Messiah College & $\mathrm{M}$ & $X$ & & $\mathrm{X}$ & $X$ & $\mathrm{X}$ & \\
\hline MidAmerica Nazarene University & $\mathrm{M}$ & $\mathrm{X}$ & & & & & $\mathrm{X}$ \\
\hline Milligan College & $\mathrm{M}$ & $\mathrm{X}$ & & & & & \\
\hline Mississippi College & $\mathrm{M}$ & $\mathrm{X}$ & & $\mathrm{X}$ & $\mathrm{X}$ & & \\
\hline Missouri Baptist University & $\mathrm{M}$ & & & & & & \\
\hline Montreat College & $\mathrm{M}$ & $\mathrm{X}$ & & $\mathrm{X}$ & & & \\
\hline Mount Vernon Nazarene University & $\mathrm{M}$ & $\mathrm{X}$ & & $\mathrm{X}$ & $\mathrm{X}$ & & $\mathrm{X}$ \\
\hline North Central University & $\mathrm{M}$ & & & & & & \\
\hline North Greenville University & $\mathrm{M}$ & $\mathrm{X}$ & & $\mathrm{X}$ & $\mathrm{X}$ & & \\
\hline North Park university & $\mathrm{M}$ & $\mathrm{X}$ & & $\mathrm{X}$ & & $\mathrm{X}$ & \\
\hline Northwest Christian university & $\mathrm{M}$ & & & & & & \\
\hline Northwest Nazarene University & $\mathrm{M}$ & $\mathrm{X}$ & & & & & $\mathrm{X}$ \\
\hline Northwest University & $\mathrm{M}$ & & & & & & \\
\hline Northwestern College & $\mathrm{M}$ & $\mathrm{X}$ & & $\mathrm{X}$ & $\mathrm{X}$ & & $\mathrm{X}$ \\
\hline Northwestern College & $\mathrm{M}$ & $\mathrm{X}$ & & $\mathrm{X}$ & $\mathrm{X}$ & $\mathrm{X}$ & \\
\hline Nyack College & $\mathrm{M}$ & $\mathrm{X}$ & & $\mathrm{X}$ & $\mathrm{X}$ & $\mathrm{X}$ & $\mathrm{X}$ \\
\hline Oklahoma Baptist University & $\mathrm{M}$ & $\mathrm{X}$ & & $\mathrm{X}$ & $\mathrm{X}$ & & $\mathrm{X}$ \\
\hline Oklahoma Christian university & $\mathrm{M}$ & $\mathrm{X}$ & & $\mathrm{X}$ & $\mathrm{X}$ & & $\mathrm{X}$ \\
\hline Oklahoma Wesleyan University & $\mathrm{M}$ & & & & & & \\
\hline Olivet Nazarene University & $\mathrm{M}$ & $\mathrm{X}$ & & $\mathrm{X}$ & $\mathrm{X}$ & & $\mathrm{X}$ \\
\hline Oral Roberts University & $\mathrm{M}$ & $\mathrm{X}$ & & $\mathrm{X}$ & & $\mathrm{X}$ & $\mathrm{X}$ \\
\hline Palm Beach Atlantic University & $\mathrm{M}$ & $\mathrm{X}$ & & $\mathrm{X}$ & & & $\mathrm{X}$ \\
\hline Pepperdine University & A & $\mathrm{X}$ & & & & $\mathrm{X}$ & \\
\hline Point Loma Nazarene University & $\mathrm{M}$ & $\mathrm{X}$ & & $\mathrm{X}$ & & $\mathrm{X}$ & \\
\hline Redeemer University College & $\mathrm{M}$ & $\mathrm{X}$ & & & & $\mathrm{X}$ & \\
\hline Regent University & $\mathrm{M}$ & & & & & & \\
\hline Roberts Wesleyan College & $\mathrm{M}$ & $\mathrm{X}$ & & $\mathrm{X}$ & $\mathrm{X}$ & $\mathrm{X}$ & \\
\hline Samford University & A & $\mathrm{X}$ & $\mathrm{X}$ & $\mathrm{X}$ & $\mathrm{X}$ & & \\
\hline San Diego Christian College & $\mathrm{M}$ & $\mathrm{X}$ & & $\mathrm{X}$ & $\mathrm{X}$ & $\mathrm{X}$ & \\
\hline Seattle Pacific University & $\mathrm{M}$ & $\mathrm{X}$ & & $\mathrm{X}$ & $\mathrm{X}$ & & \\
\hline Shorter University & $\mathrm{M}$ & $\mathrm{X}$ & & $\mathrm{X}$ & $\mathrm{X}$ & $\mathrm{X}$ & \\
\hline Simpson University & $\mathrm{M}$ & $\mathrm{X}$ & & & & $\mathrm{X}$ & \\
\hline Southeastern University & $\mathrm{M}$ & $\mathrm{X}$ & & $\mathrm{X}$ & $\mathrm{X}$ & & $\mathrm{X}$ \\
\hline Southern Nazarene university & $\mathrm{M}$ & $\mathrm{X}$ & & $\mathrm{X}$ & $\mathrm{X}$ & & $\mathrm{X}$ \\
\hline Southern Wesleyan university & $\mathrm{M}$ & $\mathrm{X}$ & & $\mathrm{X}$ & & $\mathrm{X}$ & \\
\hline
\end{tabular}


HONORS PROGRAM AT A FAITH-BASED UNIVERSITY

\begin{tabular}{|c|c|c|c|c|c|c|c|}
\hline Institution & $\begin{array}{l}\text { CCCU } \\
\text { Status }\end{array}$ & $\begin{array}{l}\text { Honors } \\
\text { Program }\end{array}$ & $\begin{array}{l}\text { Honors } \\
\text { College }\end{array}$ & $\begin{array}{l}\text { Honors } \\
\text { Courses }\end{array}$ & General & $\begin{array}{l}\text { Field- } \\
\text { specific }\end{array}$ & $\begin{array}{l}\text { NCHC } \\
\text { Member }\end{array}$ \\
\hline Southwest Baptist University & $\mathrm{M}$ & $X$ & & $\mathrm{X}$ & $\mathrm{X}$ & $\mathrm{X}$ & $\mathrm{X}$ \\
\hline Spring Arbor University & $\mathrm{M}$ & $\mathrm{X}$ & & $\mathrm{X}$ & $\mathrm{X}$ & $\mathrm{X}$ & \\
\hline Sterling college & $\mathrm{M}$ & $\mathrm{X}$ & & $\mathrm{X}$ & $\mathrm{X}$ & & \\
\hline Tabor college & $\mathrm{M}$ & & & & & & \\
\hline Taylor University & $\mathrm{M}$ & $\mathrm{X}$ & & $\mathrm{X}$ & $\mathrm{X}$ & & \\
\hline Toccoa Falls College & $\mathrm{M}$ & & & & & & \\
\hline Trevecca Nazarene University & $\mathrm{M}$ & & & & & & \\
\hline Trinity Christian college & $\mathrm{M}$ & $\mathrm{X}$ & & $\mathrm{X}$ & & $\mathrm{X}$ & $\mathrm{X}$ \\
\hline Trinity International university & $\mathrm{M}$ & $\mathrm{X}$ & & $\mathrm{X}$ & $\mathrm{X}$ & $\mathrm{X}$ & \\
\hline Trinity Western University & $\mathrm{M}$ & $\mathrm{X}$ & & & & $\mathrm{X}$ & \\
\hline Union University & $\mathrm{M}$ & $\mathrm{X}$ & & $\mathrm{X}$ & $\mathrm{X}$ & $\mathrm{X}$ & $\mathrm{X}$ \\
\hline University of Mary Hardin-Baylor & $\mathrm{M}$ & $\mathrm{X}$ & & $\mathrm{X}$ & & $\mathrm{X}$ & $\mathrm{X}$ \\
\hline University of Mobile & $\mathrm{M}$ & $\mathrm{X}$ & & $\mathrm{X}$ & $\mathrm{X}$ & & \\
\hline University of Sioux Falls & $\mathrm{M}$ & $\mathrm{X}$ & & $\mathrm{X}$ & $\mathrm{X}$ & $\mathrm{X}$ & $\mathrm{X}$ \\
\hline University of the Southwest & $\mathrm{M}$ & & & & & & \\
\hline $\begin{array}{l}\text { Vanguard University of Southern } \\
\text { California }\end{array}$ & M & & & & & & \\
\hline Warner Pacific College & $\mathrm{M}$ & & & & & & \\
\hline Warner university & $\mathrm{M}$ & & & & & & \\
\hline Waynesburg University & $\mathrm{M}$ & $\mathrm{X}$ & & $\mathrm{X}$ & $\mathrm{X}$ & & \\
\hline Westmont College & $\mathrm{M}$ & $\mathrm{X}$ & & $\mathrm{X}$ & & $\mathrm{X}$ & \\
\hline Wheaton College & $\mathrm{M}$ & $\mathrm{X}$ & & & & $\mathrm{X}$ & \\
\hline Whitworth University & $\mathrm{M}$ & $\mathrm{X}$ & & $\mathrm{X}$ & & $\mathrm{X}$ & $\mathrm{X}$ \\
\hline Williams Baptist College & $\mathrm{M}$ & & & & & & \\
\hline York college & $\mathrm{M}$ & & & & & & \\
\hline $\begin{array}{r}\text { Totals } \\
\end{array}$ & 118 & 86 & 10 & & 67 & 39 & 38 \\
\hline
\end{tabular}




\section{Appendix B}

\section{Participant Consent Form}

\section{Consent to Participate in a Research Study \\ Researcher: Carla D. Gaines \\ Home: 937-376-4283 Cell: 937-267-1301}

Identification of Project: Influences of an Honors Program on Students at a Faith-based University: A Qualitative Study

Purpose of Research: The purpose of this qualitative study is to gain an understanding of the experiences and perspectives of senior students completing the honors program at a faith-based university. This study will explore the influence of this program on the academic, intellectual, social, and spiritual development of these students. You have been invited to participate in this study because you are a senior student in the honors program at this institution. Individuals must be 18 year of age or older to participate.

Procedures: Participation in this study will involve an individual interview, lasting 60 to 90 minutes. The interview will occur at a designated area on the campus of this institution. The interview will be conducted with senior students in the honors program. The interview will be audio recorded and transcribed verbatim. Follow-up communication via email will occur to allow the participants to verify the transcribed interviews and for the interviewer to ask any additional questions for clarity or understanding. Follow-up meetings will be requested only if necessary.

Risks/Discomfort: You should not encounter any anticipated risks through participation in this research study. Participants are encouraged to be open and honest with their responses. Such responses could potentially create discomfort. Any such situations will be handled with the utmost sensitivity and discretion.

Benefits: This study will provide a better understanding of the experiences and perspectives of honors program members at a faith-based university. This information may be used as a method for refining or developing existing honors programs at this institution and others like it. You will not receive any payment for participating in this research study.

Confidentiality: Interviews will be audio recorded to preserve accuracy of the discussion. Recordings will be transcribed and saved as computer files. All computer files, handwritten notes, and any other materials related to this research will be kept in a secured safe box. You will be assigned an alias to protect your identity, which will be used in all transcripts and reporting of results. Results of the study will be reported as summaries with some direct quotations, using aliases when necessary. Only the researcher, the research advisor, and a carefully selected transcriber (if necessary), will have access to audio recordings and transcripts. You will have the opportunity to review the interview transcript for accurate representation of your thoughts, including the option 
to edit portions of the transcript, if necessary. All research materials, including audio recordings, transcripts, and notes, will be retained for a period of three years following submission of the thesis. Results may be used for publications or professional conferences, but only summaries or quotes with aliases will be used. Consent forms will be kept in a secure safe box, separate from audio recordings and transcripts.

Rights of Participants: As a participant, you have the right to ask questions at any time regarding this study and have those questions answered.

- Researcher - Carla Gaines: (Home) 937-376-4283 or (Cell) 937-267-1301

- Research Advisor - Dr. Michael Firmin: 937-766-3242

- Chair of Cedarville University Institutional Review Board Dr. Andrew Runyan: 937-766-3840

Freedom to Withdraw: You are free to decline participation in this study or to withdraw at any time without negatively influencing your relationship with the investigators, the institution, or the honors program. Your decision to withdraw will not result in any loss of benefits to which you are otherwise entitled.

Consent: Providing your signature on this consent form indicates your willingness to participate in this study with full knowledge of the purpose of the study, the procedures, risks, benefits, rights as a participant, and the freedom to withdraw.

I HAVE READ ALL THIS INFORMATION. I AGREE TO PARTICIPATE IN THIS STUDY. I HAVE RECEIVED A COPY OF THIS FORM FOR MY OWN INFORMATION.

I permit the interview to be audio recorded.

Participant Name (Please Print)

Participant Signature

Date

Interviewer Signature

Date 
HONORS PROGRAM AT A FAITH-BASED UNIVERSITY

\section{Appendix C}

\section{Honors Program Mission Statement and Objectives}

\section{Mission Statement:}

The mission of Cedarville University Honors Program is to provide an enhanced and supportive learning community, based in a rigorous integrated and interdisciplinary liberal arts curriculum, for highly capable and motivated students, in order to encourage them to develop a Christian life and mind by stimulating their intellectual curiosity, broadening their perspectives on the world, and deepening their love of God and sense of vocation in service to Him.

Objectives:

1. To recruit and retain highly qualified and motivated students in the Honors Program.

2. To develop and maintain a broad degree of support for Honors education on Cedarville's campus.

3. To develop students with an interdisciplinary view of learning, who synthesize knowledge across disciplinary boundaries.

4. To develop students who can, with depth and breadth, "think Christianly," responding with clarity, humility, strength, and compassion to issues, events, people, and ideas in our history as well as in our present day, from a definitively Christian perspective. 


\section{Appendix D}

\section{Honors Program Curriculum and Course Offerings}

\section{A. The Making of the Modern Mind (HON-1010, 1020) - The 10 semester hour}

freshman course sequence, integrating the history, philosophy, and arts of Western culture.

If both HON-1010 and HON-1020 are taken, then the student receives general education credit for the following courses:

- HUM-1400 - Introduction to the Humanities (3 semester hours)

- Humanities Elective (3 semester hours) [can replace BEPH-2200, Introduction to Philosophy, or a 2000-level philosophy elective if required for a major or minor]

- History Elective (3 semester hours)

If either HON-1010 or HON-1020 is taken individually, then the 5 semester hours earned by the student can be designated as either humanities or history general education credits.

B. Honors Seminars (2 required) - Two semester hours each, exploring interdisciplinary themes across a wide variety of subjects:

- Aesthetics: An introduction to the study of art, beauty, and other aesthetic values through an exploration of classical and contemporary theorists, critics, and artists.

- Body and Soul: Foundations for Human Personhood: An interdisciplinary study of human valuing from the perspectives of theology, philosophy, psychology, biology, and neuroscience.

- Chance, Emergence, or Design: The origin of complexity and order in the universe is studied from three different perspectives: Neo-Darwinism, Emergence, and Creation. 


\section{HONORS PROGRAM AT A FAITH-BASED UNIVERSITY}

- Contemporary Global Issues: An introduction to and critical assessment of globalplanetary problems, the global economy, environmental issues, human rights, and basic human needs.

- Creativity: The Birth of a Notion: An examination of creativity as one of the distinguishing marks of God's image in humans and as an essential component of all artistic expression.

- Culture and Health: An analysis of situations in which cross-cultural dilemmas emerge from the interaction of culture and health; models for resolution are created.

- Gender, Politics, and Communication: An investigation of the place of women in American society since 1860 , the expectations placed on them, and the influences they have had upon society.

- Image and Word in a Visual Culture: Inquiry into the tension between image and word in Jewish and Christian thought and the implications for Christians living in a visual culture.

- Perspectives on Friendship, Love, and Romance: An exploration of friendship, love, and romance from historical, theological, and philosophical perspectives.

- Postmodernism: An interdisciplinary analysis, critique, and response to postmodern ideas as they are reflected in aspects of contemporary culture such as architecture, art, education, literature, philosophy, politics, religion, and science.

- $\quad$ Reading and Writing the Literature of the Natural Environment: A study in both the reading and the writing of the literature surrounding "environmentalism." 
- The Rhetoric of Faith in the Christian Tradition: A study of significant examples of confessions, creeds, and prayers in Christian history, analyzing their rhetorical structures and devotional purposes.

- Romanticism and Its Offspring: A study of the development of poetry and music from 1800 to our present postmodern pop culture in light of the larger philosophical developments of the last two centuries.

- Science and Religion: Middle Ages to Darwin: A seminar centering on major primary sources in the history of science, exploring the historical relationship of science and religion, particularly Christian theology, from the late Middle Ages to the Darwinian Revolution.

C. Senior Honors Colloquium or Senior Research Project - Two semester hours, tying together themes and experiences from the first three years of the program 


\section{Appendix E}

\section{Personal \& Academic Characteristics of Participants}

\begin{tabular}{|c|c|c|c|c|c|c|c|}
\hline Alias & Age & Gender & Major & Department & $\begin{array}{c}\text { Add'l Majors \& } \\
\text { Minors }\end{array}$ & $\begin{array}{l}\text { "Advanced" } \\
\text { Education } \\
\text { Experiences }\end{array}$ & $\begin{array}{c}\text { Post- } \\
\text { Graduate } \\
\text { Goals }\end{array}$ \\
\hline Alexis & 21 & $\mathrm{~F}$ & $\begin{array}{l}\text { Music - Cello } \\
\text { Performance }\end{array}$ & $\begin{array}{l}\text { Music \& } \\
\text { Worship }\end{array}$ & & $\begin{array}{l}\text { Home } \\
\text { schooled, } \\
\text { debate, speech }\end{array}$ & Master's \\
\hline Cassie & 22 & $\mathrm{~F}$ & English & $\begin{array}{l}\text { English, } \\
\text { Literature \& } \\
\text { Modern } \\
\text { Languages }\end{array}$ & Spanish* & $\begin{array}{l}\text { Honors } \\
\text { courses, AP } \\
\text { courses }\end{array}$ & $\mathrm{n} / \mathrm{a}$ \\
\hline Daryl & 21 & $\mathrm{M}$ & Accounting & $\begin{array}{l}\text { Business } \\
\text { Administration }\end{array}$ & Finance* & $\begin{array}{l}\text { Honors } \\
\text { courses, AP } \\
\text { courses, Gifted } \\
\text { program }\end{array}$ & $\mathrm{n} / \mathrm{a}$ \\
\hline Dawn & 22 & $\mathrm{~F}$ & $\begin{array}{l}\text { Keyboard } \\
\text { Pedagogy }\end{array}$ & $\begin{array}{l}\text { Music \& } \\
\text { Worship }\end{array}$ & Church Music & $\begin{array}{l}\text { Honors } \\
\text { courses, AP } \\
\text { courses, Gifted } \\
\text { program }\end{array}$ & $\mathrm{n} / \mathrm{a}$ \\
\hline Devon & 21 & $\mathrm{M}$ & Psychology & Psychology & $\begin{array}{l}\text { Biology: Pre- } \\
\text { Med*, Bioethics }\end{array}$ & $\begin{array}{l}\text { Home } \\
\text { schooled }\end{array}$ & Doctoral \\
\hline Drew & 22 & $\mathrm{M}$ & Psychology & Psychology & & Honors courses & $\begin{array}{l}\text { Master's, } \\
\text { Doctoral }\end{array}$ \\
\hline Dustin & 20 & $\mathrm{M}$ & Psychology & Psychology & & $\begin{array}{l}\text { Honors } \\
\text { courses, AP } \\
\text { courses }\end{array}$ & $\begin{array}{l}\text { Master's, } \\
\text { Doctoral }\end{array}$ \\
\hline Erica & 21 & $\mathrm{~F}$ & $\begin{array}{l}\text { AYA } \\
\text { Mathematics } \\
\text { Education }\end{array}$ & $\begin{array}{l}\text { Science \& } \\
\text { Mathematics }\end{array}$ & $\begin{array}{l}\text { Computer } \\
\text { Science }\end{array}$ & $\begin{array}{l}\text { Honors } \\
\text { courses, AP } \\
\text { courses }\end{array}$ & Master's \\
\hline Esther & 20 & $\mathrm{~F}$ & $\begin{array}{l}\text { International } \\
\text { Studies: } \\
\text { Social } \\
\text { Science } \\
\end{array}$ & $\begin{array}{l}\text { History \& } \\
\text { Government }\end{array}$ & $\begin{array}{l}\text { Economics, } \\
\text { Philosophy and } \\
\text { Religion }\end{array}$ & AP courses & $\begin{array}{l}\text { Master's, } \\
\text { Doctoral }\end{array}$ \\
\hline Heather & 21 & $\mathrm{~F}$ & Psychology & Psychology & Philosophy & $\begin{array}{l}\text { Honors } \\
\text { courses, AP } \\
\text { courses }\end{array}$ & Doctoral \\
\hline Hillary & 20 & $\mathrm{~F}$ & $\begin{array}{l}\text { Political } \\
\text { Science }\end{array}$ & $\begin{array}{l}\text { History \& } \\
\text { Government }\end{array}$ & Music & $\begin{array}{l}\text { Honors } \\
\text { courses, home } \\
\text { schooled, } \\
\text { debate, } \\
\text { forensics }\end{array}$ & J.D. in law \\
\hline Jackson & 20 & $\mathrm{M}$ & $\begin{array}{l}\text { Molecular/ } \\
\text { Cellular } \\
\text { Biology }\end{array}$ & $\begin{array}{l}\text { Science \& } \\
\text { Mathematics }\end{array}$ & & AP courses & $\begin{array}{l}\text { Doctoral, } \\
\text { M.D. }\end{array}$ \\
\hline Jacob & 22 & $\mathrm{M}$ & $\begin{array}{l}\text { Political } \\
\text { Science }\end{array}$ & $\begin{array}{l}\text { History \& } \\
\text { Government }\end{array}$ & $\begin{array}{l}\text { International } \\
\text { Relations, Latin } \\
\text { American } \\
\text { Studies, Spanish }\end{array}$ & $\begin{array}{l}\text { Honors } \\
\text { Courses }\end{array}$ & $\begin{array}{l}\text { Master's, } \\
\text { Doctoral, } \\
\text { J.D. in law }\end{array}$ \\
\hline Jeff & 21 & $\mathrm{M}$ & $\begin{array}{l}\text { History and } \\
\text { Political } \\
\text { Science }\end{array}$ & $\begin{array}{l}\text { History \& } \\
\text { Government }\end{array}$ & $\begin{array}{l}\text { Philosophy and } \\
\text { Religion }\end{array}$ & $\begin{array}{l}\text { Dual } \\
\text { Enrollment }\end{array}$ & $\begin{array}{l}\text { Doctoral, } \\
\text { J.D. in law }\end{array}$ \\
\hline
\end{tabular}


HONORS PROGRAM AT A FAITH-BASED UNIVERSITY

\begin{tabular}{|c|c|c|c|c|c|c|c|}
\hline Alias & Age & Gender & Major & Department & $\begin{array}{c}\text { Add'l Majors \& } \\
\text { Minors }\end{array}$ & $\begin{array}{l}\text { "Advanced" } \\
\text { Education } \\
\text { Experiences }\end{array}$ & $\begin{array}{c}\text { Post- } \\
\text { Graduate } \\
\text { Goals } \\
\end{array}$ \\
\hline Karen & 22 & $\mathrm{~F}$ & Psychology & Psychology & & $\begin{array}{l}\text { Honors } \\
\text { courses, AP } \\
\text { courses }\end{array}$ & Master's \\
\hline Kathy & 22 & $\mathrm{~F}$ & Marketing & $\begin{array}{l}\text { Business } \\
\text { Administration }\end{array}$ & $\begin{array}{l}\text { Organizational } \\
\text { Communications }\end{array}$ & $\begin{array}{l}\text { Honors } \\
\text { Society, Dual } \\
\text { Enrollment }\end{array}$ & Master's \\
\hline Keith & 22 & $\mathrm{M}$ & $\begin{array}{l}\text { Pre-seminary } \\
\text { Bible }\end{array}$ & $\begin{array}{l}\text { Biblical \& } \\
\text { Ministries } \\
\text { Studies }\end{array}$ & Greek, Spanish & $\begin{array}{l}\text { AP courses, } \\
\text { Gifted program }\end{array}$ & Doctoral \\
\hline Kylie & 22 & $\mathrm{~F}$ & $\begin{array}{l}\text { International } \\
\text { Studies: } \\
\text { Social } \\
\text { Science }\end{array}$ & $\begin{array}{l}\text { History \& } \\
\text { Government }\end{array}$ & $\begin{array}{l}\text { East Asian } \\
\text { Studies }\end{array}$ & AP courses & Master's \\
\hline Matt & 22 & $\mathrm{M}$ & Physics & $\begin{array}{l}\text { Science \& } \\
\text { Mathematics }\end{array}$ & Math & AP courses & Master's \\
\hline Megan & 21 & $\mathrm{~F}$ & Biology & $\begin{array}{l}\text { Science \& } \\
\text { Mathematics }\end{array}$ & Music & $n / a$ & Master's \\
\hline Michaela & 21 & $\mathrm{~F}$ & Biology & $\begin{array}{l}\text { Science \& } \\
\text { Mathematics }\end{array}$ & & $\begin{array}{l}\text { AP courses, } \\
\text { Honors Society }\end{array}$ & Doctoral \\
\hline Natalie & 21 & $\mathrm{~F}$ & $\begin{array}{l}\text { Mechanical } \\
\text { Engineering }\end{array}$ & $\begin{array}{l}\text { Engineering \& } \\
\text { Computer } \\
\text { Science }\end{array}$ & & $\begin{array}{l}\text { Dual } \\
\text { Enrollment }\end{array}$ & Master's \\
\hline Neil & 22 & $\mathrm{M}$ & $\begin{array}{l}\text { Mechanical } \\
\text { Engineering }\end{array}$ & $\begin{array}{l}\text { Engineering \& } \\
\text { Computer } \\
\text { Science }\end{array}$ & & $\begin{array}{l}\text { Honors } \\
\text { courses, AP } \\
\text { courses }\end{array}$ & Master's \\
\hline Patrick & 21 & $\mathrm{M}$ & Physics & $\begin{array}{l}\text { Science \& } \\
\text { Mathematics }\end{array}$ & $\begin{array}{l}\text { Mathematics*, } \\
\text { Philosophy }\end{array}$ & $\mathrm{n} / \mathrm{a}$ & Doctoral \\
\hline Seth & 20 & $\mathrm{M}$ & Physics & $\begin{array}{l}\text { Science \& } \\
\text { Mathematics }\end{array}$ & $\begin{array}{l}\text { Computer } \\
\text { Science, Math }\end{array}$ & AP courses & Master's \\
\hline
\end{tabular}

* Denotes a second complete degree program 


\section{Appendix F}

\section{Extra-Curricular Involvement of Participants}

\begin{tabular}{|c|c|c|c|c|}
\hline Alias & $\begin{array}{c}\text { Residence } \\
\text { Status }\end{array}$ & Work Status & $\begin{array}{l}\text { Work } \\
\text { Commitment } \\
\text { (in hours) }\end{array}$ & $\begin{array}{c}\begin{array}{c}\text { Extra-Curricular Activities (senior year and } \\
\text { leadership positions) }\end{array} \\
\end{array}$ \\
\hline Alexis & Hall & On campus & $<5$ & $\begin{array}{l}\text { Soli Deo Gloria (Music Service Organization, President), } \\
\text { Student Academic Advisory Board (Senior Music Rep.) }\end{array}$ \\
\hline Cassie & Hall & On campus & $5-10$ & $\begin{array}{l}\text { TDK (Honors Organization), Parent's Night Out Ministry, } \\
\text { Sunday School Teaching }\end{array}$ \\
\hline Daryl & Hall & On campus & $<5$ & $\begin{array}{l}\text { Accounting Society (President), Delta Mu Delta } \\
\text { (Business Honor Society), SIFE (Students in Free } \\
\text { Enterprise }\end{array}$ \\
\hline Dawn & Hall & On campus & $5-10$ & HeartSong Travelling Team, Concert Chorale \\
\hline Devon & Off-campus & Off campus & $15-20$ & Debate Team \\
\hline Drew & Off-campus & On campus & $<5$ & $\begin{array}{l}\text { TDK (Honors Organization), Comedy Team, Urban } \\
\text { Outreach }\end{array}$ \\
\hline Dustin & Off-campus & on campus & $5-10$ & $\begin{array}{l}\text { Psychology Organization (Chaplain), Discipleship Small } \\
\text { Group Leader, Brother-Brother Clark County Jail } \\
\text { Ministry (Leader) }\end{array}$ \\
\hline Erica & Hall & Off campus & $<5$ & $\mathrm{n} / \mathrm{a}$ \\
\hline Esther & Hall & On campus & $5-10$ & $\begin{array}{l}\text { History \& Government Organization, Honors Political } \\
\text { Science Society }\end{array}$ \\
\hline Heather & Off-campus & On campus & $5-10$ & TDK (Honors Organization) \\
\hline Hillary & Off-campus & On campus & $15-20$ & $\begin{array}{l}\text { Phi Epsilon Beta (Women's Social Organization), } \\
\text { HeartSong Touring Teams }\end{array}$ \\
\hline Jackson & Off-campus & On campus & $5-10$ & $\begin{array}{l}\text { Student Government Association (Philanthropy director), } \\
\text { SAAB (Student Academic Advisory Board, president), } \\
\text { Chi Theta Pi (Pre-med org, activity director) }\end{array}$ \\
\hline Jacob & Hall & On campus & $15-20$ & $\begin{array}{l}\text { Resident Assistant, Tutor, Cross Country Team Captain, } \\
\text { Track team Captain }\end{array}$ \\
\hline Jeff & Hall & On campus & $10-15$ & $\begin{array}{l}\text { Student Government (Class Council, Student Court, } \\
\text { Senior Gift Cmte., ), Community Ministries Council, All } \\
\text { Nations Bible Fellowship, Changing Lives Now, Good } \\
\text { News Jail \& Prison Ministry }\end{array}$ \\
\hline Karen & Off-campus & On campus & $5-10$ & $\mathrm{n} / \mathrm{a}$ \\
\hline Kathy & Hall & On campus & $5-10$ & $\begin{array}{l}\text { TDK (Honors Organization), Intramural Sports, Dayton } \\
\text { Gospel Mission Team, Local Church }\end{array}$ \\
\hline Keith & Off-campus & $\mathrm{N}$ & & $\begin{array}{l}\text { Varsity Tennis, TDK (Honors Organization), Coach kid's } \\
\text { church basketball league, food pantry ministry }\end{array}$ \\
\hline Kylie & Off-campus & On campus & $5-10$ & $\begin{array}{l}\text { International Justice Mission, German Club, Mode United } \\
\text { Nations, Ministry Leader for Chinese Church Ministry }\end{array}$ \\
\hline Matt & Hall & On campus & $10-15$ & $\begin{array}{l}\text { Intramural Sports, TDK (Honors Organization), Mu } \\
\text { Kappa (Missionary Kid Organization) }\end{array}$ \\
\hline Megan & Off-campus & On campus & $10-15$ & One Voice Gospel Choir, Nursery, Worship Team \\
\hline Michaela & Hall & Off campus & $10-15$ & TDK (Honors Organization), The Riding Centre \\
\hline Natalie & Hall & $\mathrm{N}$ & & $\begin{array}{l}\text { Cross-Country, Track, Solar Boat Team, Tau Beta Pi } \\
\text { (Engineering Honors Org, secretary) }\end{array}$ \\
\hline Neil & Hall & On campus & $10-15$ & Intramural Sports, Resident Life Assistant \\
\hline Patrick & Off-campus & $\mathrm{N}$ & & Greene County Juvenile Detention Center \\
\hline Seth & Hall & On campus & $<5$ & Intramural sports \\
\hline
\end{tabular}




\section{Appendix G}

\section{Interview Guide: Student Cohort 1}

\section{Student Interview Guide}

Thank you for setting aside some time to meet with me for this interview. As I mentioned at your class several days ago, I am interested in your experiences in this honors program and what influence these experiences have had on you.

For verification on the recording, we have reviewed the consent form, correct? Answer\} And you acknowledge that you willingly participate in this interview and have agreed to audio recording the interview? AAnswer\} Thank you. Let's begin.

First, I'd like you to tell me about the honors program in general. Let's say I am a future student, considering being a part of the honors program, how would you describe it to me?

What do you consider to be the strengths of the honors program?

What do you consider to be the weaknesses of the honors program?

What do you like about the honors program?

What do you dislike, if anything, about the honors program?

Your answers have been very helpful. Thank you. Now I'd like to understand a little more about your background as an honors student at this school. To begin with, what factors influenced your decision to become a student at this institution?

What then lead you to participate in the honors program?

Since then, what has influenced you to continue participating in the program through graduation?

How do you feel about being an honors student at this institution?

Thank you for sharing your background with me. This will definitely help my understanding of your perspectives. Next I'd like you to think about the influence the honors program has had on you as a student and as a person? In what ways do you think you have changed during your time here at this institution (Academically, Intellectually, Spiritually, Socially)?

What experiences in the honors program do you think contributed to these changes?

What experiences in the honors program do you think have influenced you plans for the future most? 


\section{HONORS PROGRAM AT A FAITH-BASED UNIVERSITY}

According to some of the faculty I have talked with, and other documents I've looked at, "integration," both between disciplines and between "beliefs and practice," is a key outcome of this program. How would you describe the "integration" you have experienced or practiced as an honors student?

[If not addressed in above] Since this institution clearly has a mission related to shaping spirituality in the students, in what ways has participation in the honors program shaped your own spiritual beliefs and practices?

How would you compare your experiences in the honors program to your non-honors experiences in general education?

What about compared to your experiences specific to your major?

What would you change about the program, if you could? How would you improve it?

Thank you again, so much for your willingness to participate in this interview. Your thoughts have been very beneficial to my study. Finally, is there anything at all about your experiences as an honors student that you'd like to say that we didn't cover?

Is there anything you thought I should have asked, but didn't? 


\section{Appendix H}

\section{Interview Guide: Student Cohort 2}

\section{Student Interview Guide}

Thank you for setting aside some time to meet with me for this interview. As I mentioned at your class several days ago, I am interested in your experiences in this honors program and what influence these experiences have had on you.

For verification on the recording, we have reviewed the consent form, correct? Answer\} And you acknowledge that you willingly participate in this interview and have agreed to audio recording the interview? Answer\} Thank you. Let's begin.

First, I'd like you to tell me a little bit about your background as a student in the honors program at Cedarville. What factors led you to become a student at this institution?

What then lead you to participate in the honors program?

Since then, what has influenced you to continue participating in the program through completion?

Thank you that background. Now I'd like to understand better how you feel that your experiences in the honors program have influenced you. How do you think that your time in the honors program have been positive or negative experiences for you?

How do you think your honors experiences have benefited or hindered your academic development? What experiences do you think contributed to this development?

How do you think your honors experiences have benefited or hindered your spiritual development? What experiences do you think contributed to this development?

What pros and cons do you see about being an honors student at Cedarville University?

Thank you very much. I have some further questions about your experiences within the honors program. How would you describe the honors program as a community?

How would you respond to the following statement: How would you respond to the following statement: "The honors program (primarily MoMM), analyzes and challenges many or all "truths," "beliefs," or "worldviews," including those considered foundational to the mission of this institution and common to the background of most of the students"?

How would you respond to the following statement: I believe the honors program provides a "safe" environment?

Finally, is there anything at all about your experiences as an honors student that we didn't cover, that you think might be helpful to know? 


\section{Appendix I}

\section{Interview Guide: Honors Director}

Director Interview Guide

Thank you so much for taking part in this interview. As I mentioned during our initial contacts, I am interested in discovering what influence the students have experienced from their participation in this honors program. In order to understand the context of the students' comments, I would like your help in becoming familiar with the program itself. For verification on the recording, we have reviewed the consent form, correct? Answer\} And you acknowledge that you willingly participate in this interview and have agreed to audio recording the interview? Answer\} Thank you. Let's begin.

As I indicated in our earlier communication, I'd like to understand the basic organization of the program. First, what are the primary elements of the honors program?

What are the intended outcomes of this program?

So, how does each of the previously mentioned elements function toward those outcomes? Let's start with...

Specifically in your role as the director, what responsibilities do you have within the program?

What other responsibilities, if any, do you have?

How did the honors program develop into the form in which is currently exists?

How have you been involved with this development?

What factors motivated the development of an honors program at this institution?

Thank you. Your information has provided me with a good framework of the program. Now I'd like to cover some general questions about the program and your perceptions of it. Considering the financial burdens of college for many students, what benefits does participation in this program offer to the students? [Academically, Socially, Intellectually, Personally, Spiritually]

Which of these benefits, if any, do you believe the honors students cannot or will not obtain through other experiences at this institution?

Given that this institution has a particular spiritual mission, in what ways do you believe this program influences the students' spirituality?

What changes, if any, have you noticed in students over the course of their participation in the program? 


\section{HONORS PROGRAM AT A FAITH-BASED UNIVERSITY}

From a broader perspective, how do you believe this program serves the rest of the institution?

What do you think are the strengths of this honors program?

What do you think are the weaknesses of this honors program?

Finally, I'd like to ask a few questions about the freshman MoMM sequence. What are the goals of the MoMM sequence?

What features of this sequence do you feel best accomplish the goals listed above? What types of changes have you observed in students during their participation in the MoMM sequence?

What is the most enjoyable part of leading this course?

What is the most challenging part of leading this course?

[Additional: How would you describe your relationship with the students in this course?] Again, thank you for your cooperation. Your feedback has provided me with a rich perspective of the program that will help my understanding of the program and how it influences the students. 


\section{Appendix J}

\section{Interview Guide: Senior Colloquium Professor}

\section{Colloquium Interview Guide}

Thank you so much for taking part in this interview. As we've discussed, I am interested in discovering what influence the students have experienced from their participation in this honors program. In order to understand the context of the students' comments, I would like your help in becoming more familiar with the program itself.

For verification on the recording, we have reviewed the consent form, correct? Answer\} And you acknowledge that you willingly participate in this interview and have agreed to audio recording the interview? \{Answer\} Thank you. Let's begin. I'm going to start with some general questions about the program and your perceptions of it. What responsibilities do you have within the program?

How have you been involved, if at all, with the development of the honors program, or parts of it, into the form in which it currently exists?

Considering the financial burdens of college for many students, what benefits do you think participation in this program offers to the students? [Academically, Socially, Intellectually, Personally, Spiritually]

Which of these benefits, if any, do you believe the honors students cannot or will not obtain through other experiences at this institution?

Considering that this institution has a particular spiritual mission, in what ways do you believe this program influences the students' spirituality?

From a broader perspective, how do you believe this program serves the rest of the institution?

What do you think are the strengths of this honors program?

What do you think are the weaknesses of this honors program?

Now I'd like to move to some specific questions about the colloquium aspect of the honors program. The outcomes stated in the colloquium syllabus all address the "integration of faith and learning." First, could you please explain in a little more detail what you mean by the "integration of faith and learning".

[Clarification: These terms are rather broad; especially integration. What does "integration" look like in the students if they do it successfully? How would you describe that you or other faculty execute this concept?]

What types of changes have you observed in students during their participation in the colloquium? 


\section{HONORS PROGRAM AT A FAITH-BASED UNIVERSITY}

What is the most enjoyable part of leading this course?

What is the most challenging part of leading this course?

[Additional: How would you describe your relationship with the students in this course?]

Again, thank you for your cooperation. Your feedback has provided me with a good understanding of the colloquium that will help my understanding of the program and how it influences the students. 


\section{Appendix K}

\section{Interview Guide: Honors Professor}

Faculty Interview Guide

Thank you so much for taking part in this interview. As we've discussed, I am interested in discovering what influence the students have experienced from their participation in this honors program. In order to understand the context of the students' comments, I would like your help in becoming familiar with the program itself. For verification on the recording, we have reviewed the consent form, correct? Answer\} And you acknowledge that you willingly participate in this interview and have agreed to audio recording the interview? AAnswer\} Thank you. Let's begin.

As I indicated in our earlier communication, I'd like to learn some background for the program. What responsibilities have you had within the program?

What of these responsibilities do you still have, if any?

How did the honors program develop into the form in which is currently exists?

How have you been involved with this development?

What factors motivated the development of an honors program at this institution?

Your answers have been quite helpful. Now I'd like to cover some general questions about the program and your perceptions of it. Considering the financial burdens of college for many students, what benefits do you think participation in this program offers to the students? [Academically, Socially, Intellectually, Personally, Spiritually]

Which of these benefits, if any, do you believe the honors students cannot or will not obtain through other experiences at this institution?

Given that this institution has a particular spiritual mission, in what ways do you believe this program has influenced the students' spirituality?

What changes, if any, have you seen in students over the course of their participation in the program?

From a broader perspective, how do you believe this program serves the rest of the institution?

What do you think are the strengths of this honors program?

What do you think are the weaknesses of this honors program?

Again, thank you for your cooperation. Your feedback has provided me with a rich perspective of the program that will help my understanding of the program and how it influences the students. 
Appendix L

\section{Data Analysis Coding Key}

\begin{tabular}{|c|c|}
\hline Code & Meaning \\
\hline Interdisp & $\begin{array}{l}\text { Encourages an interdisciplinary approach to learning; addresses content in an } \\
\text { interdisciplinary fashion; integration of disciplines }\end{array}$ \\
\hline Fr & Freshman year \\
\hline So & Sophomore year \\
\hline $\mathrm{Jr}$ & Junior year \\
\hline $\mathrm{Sr}$ & Senior year \\
\hline MoMM & Making of the Modern Mind - the freshman honors sequence \\
\hline Freq & Relates to the frequency of honors classes, events, or interactions \\
\hline Purpose & Relates to the purpose of the honors program \\
\hline Prog-Eval & Evaluative statements made by the students about the honors program \\
\hline Integ & Relates to integration, generally; a holistic mentality \\
\hline Integ-Christ & Relates to integration of personal faith, Christian beliefs \\
\hline Prog-Con & Relates to the connectedness of the program's components \\
\hline Relate & Relates to building and supporting relationships with students and professors \\
\hline D-Tht & $\begin{array}{l}\text { Relates to the concept of "deep thinking," thinking that investigates and searches } \\
\text { in order to really understand a concept }\end{array}$ \\
\hline Intel+ & Encourages or is geared toward a higher intellectual level \\
\hline Intel- & Encourages or is geared toward a lower intellectual level \\
\hline O-Cont & Relates to openness of the curriculum or content in the program \\
\hline O-Dial & Relates to openness or freedom for dialogue within the program \\
\hline Trad-Cont & Focuses more on traditional content; conservative in approach \\
\hline Cr-Tht & $\begin{array}{l}\text { Relates to the concept of "critical thinking," a process and attitude of openly } \\
\text { investigating and evaluating ideas/content }\end{array}$ \\
\hline Lim & Relates to a sense of limitation on students or the program \\
\hline Found & $\begin{array}{l}\text { Builds or supports a foundation of knowledge and/or skills for all future } \\
\text { experiences }\end{array}$ \\
\hline Opp-Var & Provides opportunities for variety in experiences \\
\hline Christ & Relates to having or encouraging a Biblical/Christian influence on the experience \\
\hline Opp-Intel & Provides opportunities for intellectual development or stimulation \\
\hline Prog-Org & Relates to the organization of the program or its elements \\
\hline Choice & Relates to the availability of student choice in their experiences \\
\hline Stu-Var & $\begin{array}{l}\text { Relates to the student's desire for or enjoyment of variety in interests, pursuits, } \\
\text { subjects, etc. }\end{array}$ \\
\hline Breadth-Exp & $\begin{array}{l}\text { Provides or encourages a breadth of experiences; covers a large number of } \\
\text { topics/concepts }\end{array}$ \\
\hline Depth-Exp & $\begin{array}{l}\text { Provides or encourages a depth of experiences; provides a more complete } \\
\text { familiarity with the topics/concepts }\end{array}$ \\
\hline Prac-Ben & $\begin{array}{l}\text { Relates to practical benefits obtained by or available to students through the } \\
\text { experience }\end{array}$ \\
\hline Pass & Relates to an attitude of passivity on the part of students or professors \\
\hline Enjoy & Expression of enjoyment regarding honors experiences \\
\hline Norm & $\begin{array}{l}\text { Expressions of feeling like a typical/normal college student; do not feel "special" } \\
\text { or "gifted"; do not experience college differently }\end{array}$ \\
\hline Skill & Promotes the development of academic skills useful in all learning situations \\
\hline
\end{tabular}




\section{HONORS PROGRAM AT A FAITH-BASED UNIVERSITY}

\begin{tabular}{|c|c|}
\hline Code & Meaning \\
\hline Extend & Influences extend beyond the in-class experience \\
\hline Cont-Learn & $\begin{array}{l}\text { Relates to the attitude or development of continual learning; a desire to continue } \\
\text { learning outside of the standard school experience }\end{array}$ \\
\hline Aware & Relates to an awareness of one's self - thinking, prejudices, personality, etc. \\
\hline Guide & $\begin{array}{l}\text { Relates to student's purposes, principles, values, etc. that guide their decisions, } \\
\text { attitudes, reflections, etc. }\end{array}$ \\
\hline Change & Student indicated an experience of change in himself or herself \\
\hline Quest & Relates to questioning of beliefs, thoughts, experiences, etc. (see Bryant 2008) \\
\hline Owning & $\begin{array}{l}\text { Relates to the sense of owning one's beliefs, actions, etc.; as opposed to simply } \\
\text { claiming beliefs by association with others }\end{array}$ \\
\hline Mat-Dev & $\begin{array}{l}\text { Relates to the development of greater maturity in the student from their own } \\
\text { perspective }\end{array}$ \\
\hline Humility & $\begin{array}{l}\text { Relates to an attitude of humility in experiences, or being humbled through } \\
\text { experiences }\end{array}$ \\
\hline Articulate & Encourages the ability to articulate ideas verbally \\
\hline Dialogue & $\begin{array}{l}\text { Peer-peer or peer-professor dialogue (debate, evaluation, etc.) occurs regularly as } \\
\text { part of the in-class and out-of-class experiences }\end{array}$ \\
\hline Writing & Encourages the ability to communicate ideas in written form \\
\hline Confid & Encourages a sense of confidence in one's abilities, beliefs, or opinions \\
\hline Active & $\begin{array}{l}\text { Students experience active learning; students actively involved in their own } \\
\text { learning }\end{array}$ \\
\hline Creative & $\begin{array}{l}\text { Encourages creative thinking (artistic, imaginative or original) or aesthetic } \\
\text { concepts, develops greater appreciation for creative expressions }\end{array}$ \\
\hline Safe & $\begin{array}{l}\text { Relates to a "safe" environment; connotes an atmosphere of freedom to explore, } \\
\text { but also protection from potentially negative consequences of the process }\end{array}$ \\
\hline Lit & $\begin{array}{l}\text { Literature was actively utilized as a resource in the student's "questing” and } \\
\text { personal development }\end{array}$ \\
\hline Challenge & $\begin{array}{l}\text { Experiences push students beyond their expectations; requires genuine effort to } \\
\text { succeed }\end{array}$ \\
\hline Stu-Flex & $\begin{array}{l}\text { Student is flexible; comfortable with change and varying circumstances; affects } \\
\text { response to circumstances }\end{array}$ \\
\hline Uncert & $\begin{array}{l}\text { Student experienced or expressed uncertainty during the college education } \\
\text { process }\end{array}$ \\
\hline Intuition & $\begin{array}{l}\text { Expressed more intuitive decision process than a logical, reasoned one; examples } \\
\text { include "I just enjoyed it." Or "It just felt right." }\end{array}$ \\
\hline Prof-Interact & $\begin{array}{l}\text { Experience regular personal interaction with professors; inside and outside } \\
\text { course experiences, relates to a sense of "connectedness" to the faculty }\end{array}$ \\
\hline Stu-Center & $\begin{array}{l}\text { Professors are student-centered in their approach to course content, methods, and } \\
\text { evaluation }\end{array}$ \\
\hline Pos-Feed & Regularly experienced positive feedback, even when feedback was corrective \\
\hline Struggle & Communicated experiences of personal struggle \\
\hline Support & Experienced support during times of struggle \\
\hline GvL & Relates to the competing values of grades versus learning \\
\hline Diversity & $\begin{array}{l}\text { Experienced diversity, e.g. personalities, backgrounds, ideas, etc.; this does not } \\
\text { imply "absolute" diversity of all possibilities }\end{array}$ \\
\hline Comm & Encouraged a sense of community for the student \\
\hline Motive & $\begin{array}{l}\text { Relates to personal motivations influencing student experiences inside and } \\
\text { outside the classroom }\end{array}$ \\
\hline
\end{tabular}




\section{HONORS PROGRAM AT A FAITH-BASED UNIVERSITY}

\begin{tabular}{|c|c|}
\hline Code & Meaning \\
\hline Opp-Expo & Provided opportunities for exposure to a wide range of content, ideas, opinions \\
\hline Effective & $\begin{array}{l}\text { Encourages effectiveness (pursuit of excellence) both in academic life and other } \\
\text { areas of life; both during education and in future }\end{array}$ \\
\hline Outside & Expressed feeling like an "outsider," lacking a sense of belonging to the group \\
\hline Unity & $\begin{array}{l}\text { Encouraged a sense of Christian unity (built on foundational belief in Christ, but } \\
\text { respecting individual diversity) }\end{array}$ \\
\hline PvT & $\begin{array}{l}\text { Relates to the tension between practical (application, useful for daily life) and } \\
\text { theoretical (broad potentiality, ideas) }\end{array}$ \\
\hline Leader & Relates to the development of leaders or influence on leadership positions \\
\hline Prior & $\begin{array}{l}\text { Student experience a process of "questing" prior to honors experiences; } \\
\text { developed spiritual/intellectual foundations prior to honors experiences }\end{array}$ \\
\hline Abroad & $\begin{array}{l}\text { Experiences before or during honors included opportunities abroad (outside the } \\
\text { United States) }\end{array}$ \\
\hline Percept & $\begin{array}{l}\text { Relates to perceptions that non-honors peers/faculty have about honors students } \\
\text { or the honors program, or that honors students think they have }\end{array}$ \\
\hline Excel & $\begin{array}{l}\text { Students experience high expectations from others or themselves within honors; } \\
\text { e.g. faculty, assignments, peers }\end{array}$ \\
\hline Family & $\begin{array}{l}\text { Family members were actively utilized as a resource in the student's "questing" } \\
\text { and personal development }\end{array}$ \\
\hline Peers & $\begin{array}{l}\text { Peers, within honors and without, were actively utilized as a resource in the } \\
\text { student's "questing" and personal development }\end{array}$ \\
\hline Faculty & $\begin{array}{l}\text { Faculty, within honors and without, were actively utilized as a resource in the } \\
\text { student's "questing" and personal development }\end{array}$ \\
\hline Religious & $\begin{array}{l}\text { Religious activities (i.e. church, prayer, Bible) were actively utilized as a } \\
\text { resource in the student's "questing" and personal development }\end{array}$ \\
\hline Arrogant & $\begin{array}{l}\text { Relates to a perception of arrogance expressed by honors students or faculty by } \\
\text { other honors students }\end{array}$ \\
\hline Prof-Qual & Relates to the perceived quality of the professors \\
\hline Isolate & $\begin{array}{l}\text { Relates to the perceptions or actuality of being separated from the rest of the } \\
\text { institution or student body through honors }\end{array}$ \\
\hline Cost & $\begin{array}{l}\text { Relates to the time, effort, finances, etc. sacrificed to participate in the honors } \\
\text { program }\end{array}$ \\
\hline Fin-Aid & Relates to financial aid made available to students in the honors program \\
\hline Balance & $\begin{array}{l}\text { Relates to balancing the tensions between competing ideals found in the } \\
\text { program, institution, or life }\end{array}$ \\
\hline Prog-Ease & Relates to the ease of entering or continuing in the honors program \\
\hline Awkward & $\begin{array}{l}\text { Experiences feelings of awkwardness related to participation in the honors } \\
\text { program }\end{array}$ \\
\hline Listening & $\begin{array}{l}\text { Encourages or develops the skill of listening honestly and openly to the ideas, } \\
\text { opinions, perspectives, etc., of others }\end{array}$ \\
\hline Rebel & $\begin{array}{l}\text { Experiences periods of rebellious attitudes in connection with family or } \\
\text { institutional expectations }\end{array}$ \\
\hline Small & Relates to the size of the program or classes \\
\hline Review & Relates to the desire to revisit or review experienced previously in the program \\
\hline New & $\begin{array}{l}\text { Experiences in the honors program presented the student with ideas, methods, } \\
\text { expectations, etc. that were not previously encountered or understood before }\end{array}$ \\
\hline
\end{tabular}

